Article

\title{
A Hybrid Method for Citizen Science Monitoring of Recreational Trampling in Urban Remnants: A Case Study from Perth, Western Australia
}

\author{
Greg D. Simpson ${ }^{1, * \mathbb{C}}$, Jackie Parker ${ }^{1}$, Erin Gibbens ${ }^{2,3}$ (1) and Philip G. Ladd ${ }^{3}$ \\ 1 Harry Butler Institute, Murdoch University, South Street, Perth 6150, Australia; \\ jacqueline.parker@murdoch.edu.au \\ 2 Iluka Resources Limited, Cataby Operations, Brand Highway, Cataby 6507, Australia; \\ erin.gibbens@iluka.com \\ 3 Environmental and Conservation Sciences, College of Science, Health, Engineering and Education, \\ Murdoch University, South Street, Perth 6150, Australia; P.Ladd@murdoch.edu.au \\ * Correspondence: G.Simpson@murdoch.edu.au
}

Received: 30 October 2020; Accepted: 4 December 2020; Published: 8 December 2020

\begin{abstract}
Vegetation trampling that arises from off-trail excursions by people walking for recreation can negatively impact the structure of understory plants in natural spaces that are an essential element of urban green infrastructure in a modern city. In addition to reducing the esthetic quality and environmental values of urban remnant and replanted native vegetation, such trampling reduces the habitat that supports wildlife populations within the urban fabric. This case study draws upon several disparate methods for measuring vegetation structure and trampling impacts to produce a hybrid method that community-based citizen scientists (and land managers and other researchers) could use to simply, rapidly, and reproducibly monitor how trampling associated with urban recreation trails impacts the structure of understory vegetation. Applying the novel hybrid method provided evidence that trampling had reduced the vegetation structure adjacent to a recreational walking trail in an urban woodland remnant in Perth, Western Australia. The hybrid method also detected ecological variability at the local ecosystem-scale at a second similar woodland remnant in Perth. The hybrid sampling method utilized in this case study provides an effective, efficient, and reproducible data collection method that can be applied to recreation ecology research into aspects of trampling associated with trail infrastructure.
\end{abstract}

Keywords: citizen science; recreation ecology; vegetation trampling; urban green infrastructure

\section{Introduction}

The global phenomena of people seeking recreational opportunities to reconnect with nature are resulting in negative impacts from vegetation trampling by those in pursuit of natural area experiences [1-4]. This is especially true both for recently created remnants and for remnant vegetation long fragmented within the urban fabric that have been engulfed as cities grow to accommodate increasingly urbanized human populations [5-9]. Recreational or pedestrian trampling of vegetation adjacent to formal and informal trails (as distinct from trampling caused by livestock or large wildlife) occurs when visitors leave an established trail to observe or photograph wild animals or interesting flowering native plants or when they wish to traverse an area or to create new informal trails for their own purposes $[3,10,11]$. Exploring how the presence and utilization of recreational trails affect the composition, height, and/or density (hereafter collectively referred to as structure), and persistence of indigenous biodiversity incorporated into urban green infrastructure (UGI) is a priority for recreation ecology research. 
A systematic literature review by Ballantyne and Pickering [1] reported that trampling research specifically related to recreation trails is biased toward remote locations, with less than two in every five studies being conducted at urban or near urban sites (within $50 \mathrm{~km}$ of a city center). The same review reported that approximately six in ten studies investigated the composition of the vegetation (i.e., species present and percentage foliage cover) while less than two in ten studies examined the structure of the vegetation. That reported bias is surprising as the early review of trampling research by Liddle [12] and the method defining procedures of Cole and Bayfield [13] emphasized the importance of measuring vegetation height both pre and post trampling. More recently, the experimental work of Phillips and Newsome [14] and Pickering and Hill [15] highlight the significance of trampling damage on vegetation structure. Particularly relevant for the case study reported in this article, Phillips and Newsome [14] found that changes in the structure of the drought-tolerant sclerophyllous shrub-dominated vegetation of southwestern Australia (SWA) could be detected more rapidly than changes in cover and composition. Supported by Whinam et al. [16], Phillips and Newsome [14] (p. 269) postulated that assessing trampling induced structure change in shrub-dominated biomes "may be a more useful indicator of trampling impact than vegetation cover for short-term studies" as it may take months for severed and damaged branches to die and the full extent of the cover change to become evident. Other recreational trampling research gaps that were identified by Ballantyne and Pickering [1] included the need to extend the research of trail infrastructure impacts wider than just the trail surface and immediate edge effects, with more consideration of the structural and functional ecosystem changes caused by off-trail trampling and the longitudinal study of longer-term impacts of trail infrastructure on threatened communities and species.

Repeatedly trampled vegetation tends to be less diverse and less structured, as only the tolerant plant species are likely to persist $[10,17]$. The negative impacts of recreational trampling significantly degrade established ecosystems and prevent damaged ecosystems from regenerating, which reduces the natural values of UGI and the quality of urban nature experiences. It is important, however, to balance the negative impacts of trampling against the cultural, health, and social benefits that humans accrue from allowing complementary recreational opportunities that cause minimal ecological damage to nature spaces within UGI $[7,18,19]$. For example, allowing recreational access to remnant vegetation is critical if urban residents are to avoid the extinction of experience that occurs when individuals become disconnected from nature $[20,21]$. This phenomenon occurs when younger generations do not have the opportunity to experience the personal benefits of visiting good quality natural areas and/or they become conditioned to only experiencing degraded UGI, then a cycle of disaffection and apathy leads inevitably to further degradation or even the complete loss of natural ecosystems.

This case study investigates the impact of recreational trails on the structure of sclerophyllous shrub-dominated (Speck 1952 cited in Beard [22]) understory vegetation (hereafter understory) in two remnant ecosystems of open Banksia low woodland [22] that are fragmented within the urban fabric of Perth, Western Australia. These remnant ecosystems are ecologically important as less than 200 years of European settlement has resulted in more than $86 \%$ of the Banksia low woodlands being cleared from the Swan Coastal Plain (SCP) biogeographic region in which Perth is located $[23,24]$. The uniqueness of the vegetation of SWA combined with these levels of clearing (habitat loss) resulted in Myers et al. [25] including SWA (incorporating the SCP) in their list of global biodiversity hotspots. However, at the dawn of the 21st-century, state and local government agencies and other authorities introduced statutory and policy instruments that endeavor to reserve and conserve remnants of indigenous vegetation (locally known as bushland in SWA) as public open space within the fabric of the Perth metropolitan area $[7,26]$. Despite many of these bushland reserves only covering small areas, they are essential for both conserving indigenous biodiversity and providing cultural and social links to the natural landscape through high-quality UGI [27-30]. The persistence of bushland remnants contributes to Perth consistently ranking as one of the most livable cities on the planet [31-33]. However, that ranking is a factor in the ongoing population growth that is increasing residential densities and the spreading urban footprint of Perth [34], which is putting more pressure on the bushland of the city 
with more people wanting to connect with nature through the reactional opportunities provided by UGI $[7,34]$. In recent years, the Australian Government declared the Banksia Woodlands of the SCP to be an endangered ecological community as a direct response to the ongoing high level of clearing within the urban fabric and on the peri-urban fringe [35,36].

This case study investigated protected vegetation (i.e., located behind a conservation fence) and unfenced vegetation to elucidate the impact of trampling adjacent to recreational trail on the structure of the understory in two Banksia woodland remnants located within the UGI of Perth, Western Australia. From an ecological perspective, this study sought to characterize the impact of recreational trampling on the understory of remnant urban woodlands. From a management perspective, this study looked for evidence that conservation fencing reduced the impact of trampling on the understory adjacent to urban recreation trails. A secondary goal of this study was to demonstrate that volunteer community members (i.e., citizen scientists) could use the methods detailed in this article to assess and longitudinally monitor understory structure at the local ecosystem-scale within the natural spaces of UGI.

\section{Background to Case Study Sites}

\subsection{Selection of Case Study Sites}

Most of the remnant Banksia woodland at the Murdoch University and Lake Claremont (Figure 1) study sites had eucalypt species emerging through or growing over Banksia spp. in the type of woodland that Beard [22] classified as either "Banksia with Jarrah woodland" or "Banksia woodland with scattered Eucalypts", which is hereafter referred to as Banksia and eucalypt woodland. In the same review, Beard also reports a strong association between Banksia with Jarrah woodland and patches of "Banksia woodland" without eucalypts, and one of the sampling locations at Lake Claremont met that classification. In addition to the similarity of the dominant vegetation at those two sites, there are three other key reasons for their selection. One reason for choosing the Murdoch site was the proximity to our research base, but that site was also chosen because the remnant native vegetation was known to be in good to very good condition (as rated on the Keighery scale $[37,38]$ ) where a conservation fence separates native vegetation from a recreation trail and another sampling location where the trail infrastructure is unfenced. The second site was chosen to support the Friends of Lake Claremont (FOLC) community action group that was proposing to implement a longitudinal ecological citizen science program in remnant Banksia and eucalypt woodland and Banksia woodland ecosystems at Lake Claremont that are undergoing restoration to counter a century and a half of urban disturbance [7]. This case study provides baseline data for FOLC's citizen science program to support longitudinal monitoring of the understory structure and compare it with the understory structure in very good condition Banksia and eucalypt woodlands of the SCP.

\subsection{General Description of Case Study Sites}

Three north-south oriented aeolian dune systems that were sequentially deposited as sea levels rose and fell in response to glacial and interglacial cycles dominate the geomorphology of the western portion of the SCP $[24,39]$. The Bassendean dunes are the oldest and most eastern system, several depositional episodes created the central Spearwood dune system, and the youngest and most western Quindalup dune system began accreting approximately 7000 years ago as sea levels rose after the last glacial maximum to form the present-day coastline of the Perth region [39-41]. The Perth region experiences a Mediterranean climate with hot, dry summers and cooler, wetter winters [42,43]. The fieldwork was completed in the Austral winter and spring seasons of 2015 to 2017, which aligns with the optimum window for vegetation condition assessments in the Mediterranean climate zone of SWA [38,44].

The Murdoch University study site (Figures 1 and A1 and Figure A2 in Appendix A) is located at the intersection of the Bassendean and Spearwood dunes in Banksia and eucalypt woodland associated with the sandy alkaline soil of the Spearwood dunes $[24,45]$ with fenced and unfenced native vegetation adjacent to recreation trails. Lake Claremont lies on the intersection of the Spearwood and Quindalup 
dunes [7], and the three sampling locations at Lake Claremont (Figures 1 and A3 and Figure A4 in Appendix A) are on the sandy alkaline soil of the Quindalup dunes. The three sampling locations at this site were fenced, and unfenced locations in matched remnant Banksia and eucalypt woodland comparable to the Murdoch vegetation and the unfenced patch of Banksia woodland noted earlier. Data collectors took care to minimize the trampling of vegetation during sampling, especially in relation to shrubs in the understory and seedlings of recruiting native species.

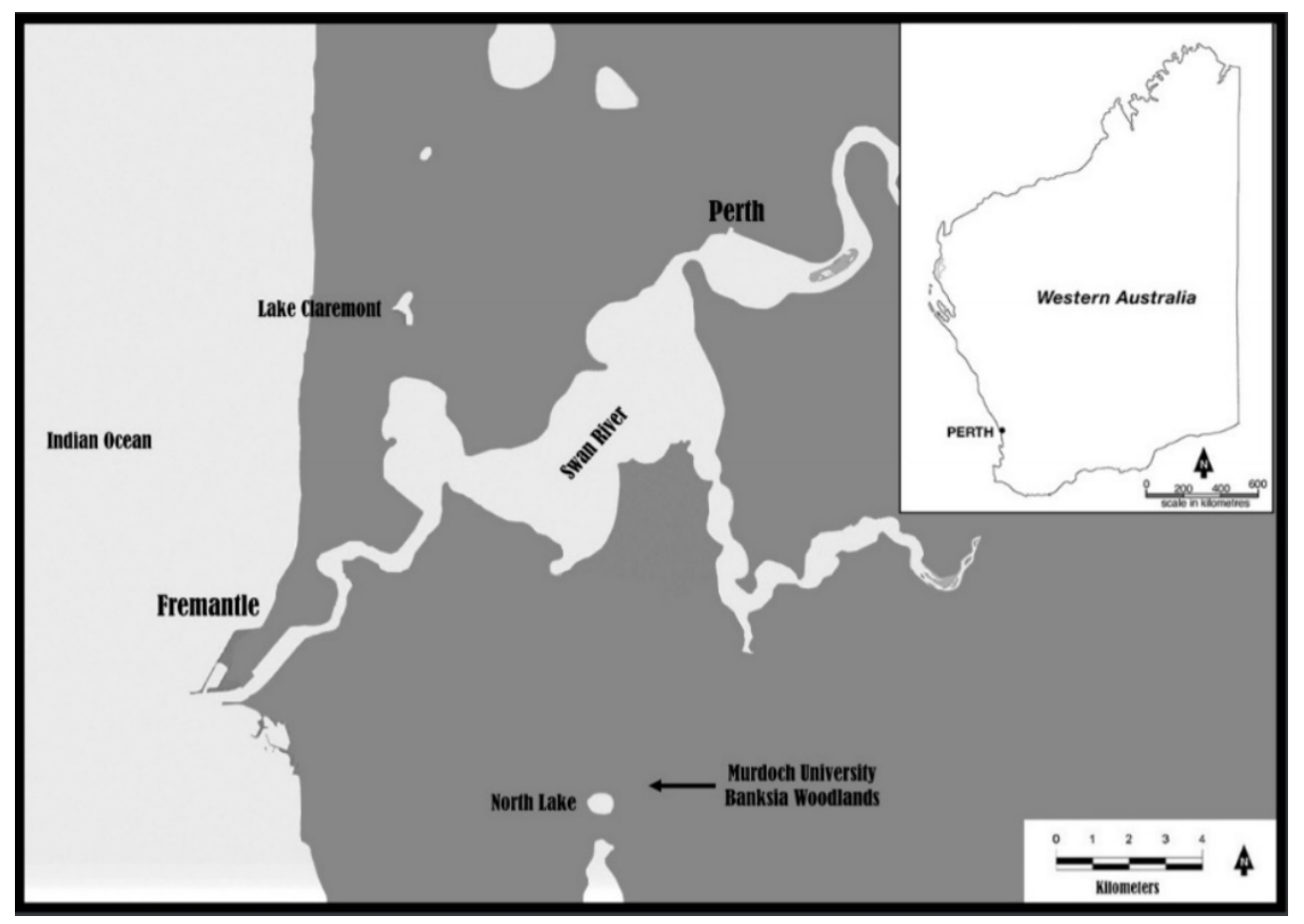

Figure 1. Location of study sites at Lake Claremont in the suburb of Claremont and Murdoch University in the suburb of Murdoch in relation to significant anthropogenic and geomorphic landscape elements within the urban fabric of Perth, Western Australia.

\subsection{Post-Colonization Land-Use at Study Sites}

The presence of fertile soils and water during the dry summer period that characterizes the Mediterranean climate of SWA combined to make wetlands such as Bibra and North Lakes, which are located to the south of the Murdoch study site, and Lake Claremont, on the eastern edge of the Claremont study site, the focus of agricultural production from the earliest days of Britain's Swan River Colony [46,47].

Post-colonization, there was considerable clearing for grazing, horticulture, and timber production in the vicinity of the Murdoch study site as the Swan River Colony developed in the second half of the 19th-century $[47,48]$. The opening decades of the 20th-century brought even greater change to the land around the Murdoch site. An expanding dairy industry was decimated in 1923 by enforced cattle culling to control an outbreak of the highly contagious Rinderpest disease [47]. The Murdoch site was purchased as part of University endowment land for the future University of Western Australia in 1905 [48]. Combined with the cattle culling, that purchase facilitated the State's Forestry Department in converting the Banksia and eucalypt woodland around the Murdoch site into a plantation of exotic pines (Pinus spp.) from 1926 onward [48]. Fortunately, the Murdoch study site retained a remnant of the indigenous vegetation that was designated as a conservation zone following the establishment of Murdoch University in the early 1970s [48]. However, a decade later, the site changed again when a road was controversially routed through remnant bushland immediately south of the Murdoch site in 1984 [49]. An access road to the Murdoch University campus and a secondary education facility were 
constructed on the western boundary of the Murdoch study site in 1994 [50,51]. The recreational trails through the remnant were installed at that time [52].

Analogously, the Lake Claremont study site is located at the southern end of the Perth Common, where imported livestock were grazed as early as 1830, and intensive horticultural production occurred on and around the wetland from the mid-19th and into the mid-20th century $[7,46]$. Rapid urbanization around Lake Claremont in the second half of the 20th century brought new threats to the indigenous ecosystems of the area. From the early 1950s, the lake was utilized as a landfill site, after which the area north and east of our study site became a golf course, and a drive-in movie theatre was built to the west of our study site when the landfill site was closed in the early 1970s [53,54].

When the local Claremont community began to recognize the environmental value of this urban remnant vegetation, approximately 30 years ago, the understory was choked by highly invasive introduce weed species, and the indigenous understory had been all but lost $[7,53,54]$. Collaborative restoration by the community and local government authority since that time has resulted in the functional minimization of introduced weeds in the understory and the reintroduction of indigenous shrubs [55], primarily the larger midstory species such as Acacia spp., Rottnest Island pine (Callitris preissii), the threatened Hackett's hopbush (Dodonaea hackettiana) and rapidly growing colonizers such as berry saltbush (Rhagodia baccata), coastal rosemary (Olearia axillaris), and thick-leaved Fan-flower (Scaevola crassifolia). A limited number of monocots have also been planted, but these do not currently influence the height or density of the understory.

To understand the structure of the vegetation at our two study sites, the environmental history post-European colonization needs to be considered against characteristics of the remnant and replanted shrub-dominated understory.

\subsection{Impact of Land-Use on Understory}

As previously mentioned, sclerophyllous shrub-dominated understory has a low resistance to physical damage because branches are easily broken or whole shrubs killed, and low resilience, where damaged vegetation takes years or even decades to recover $[4,13,56]$. These two characteristics can be attributed to the high investment that a shrub growth form puts into above-ground structures with meristems on external branches and to their slow-growth rate and low productivity compared to herbaceous and monocot understory plants $[11,12,57]$. Trampling and grazing by livestock and/or pedestrians are common sources of this physical damage, especially within urban and peri-urban remnant vegetation $[5,58,59]$. The impact of trampling and other negative pressures, such as the establishment of invasive species of plants, the introduction of plant pathogens (e.g., Phytophthora water molds), increased fire frequency, and rubbish dumping, combine to magnify the effect of disturbance along any edge at which remnant vegetation and urban fabric meet $[4,5,60]$. Ballantyne and Pickering [1] report that the impact of this edge effect can extend up to $20 \mathrm{~m}$ into remnant vegetation along a boundary where a wide gap in the canopy cover coincides with a hard surface trail constructed from introduced mediums, as is common in urban or urbanizing areas.

\subsubsection{Understory of Murdoch University Study Site}

The fenced remnant of Banksia and eucalypt woodland at the Murdoch study site is located on the type of hard-edged urban boundary described by Ballantyne and Pickering [1]. In addition, in the field, it was observed that evidence of disturbance at this sampling location might have occurred during the construction of the access road to Murdoch University and the secondary school approximately 25 years ago. Prior to the installation of the recreation trail in 1994, the vegetation of the unfenced and fenced sampling locations at Murdoch would have been largely shielded from any livestock impacts since the livestock culling occurred over 90 years ago. This timeframe is of the magnitude required for recovery of the low resistance sclerophyllous shrub-dominated vegetation of SWA to recover from any livestock trampling that occurred between 1850 and 1923 [61-63]. 


\subsubsection{Understory of Lake Claremont Study Site}

As reported above, the degraded state of the understory at the Lake Claremont sampling site and the extreme weed invasion that existed at this site less than two decades ago $[7,53,54]$ means that while the understorey has been replanted, it is still in a degraded state. Pettit et al. [58] and Standish et al. [64] report that after decades of grazing, trampling, and weed invasion, the shrub-dominated understory of woodlands in SWA is unlikely to have naturally regenerated in such a short timeframe. Because the method applied in this study assumes that the vegetation is undisturbed and spatially uniform before the installation of trail infrastructure, it was recognized that identifying trampling related impacts at the Lake Claremont study site would be problematic. However, a difference in the understory structure of the Banksia and eucalypt woodland at the unfenced sampling location was observed in the field. Further, evidence of off-trail trampling impacts was also observed in the field at the other two sampling locations at Lake Claremont.

\section{Materials and Methods}

\subsection{Evolution of the Hybrid Sampling Technique}

Reviewing the published literature identified several methodological gaps and inconsistencies in the reported methods for sampling vegetation that had or may have been impacted by recreational trampling. Those gaps and inconsistencies are summarized as follows:

Cole and Bayfield [13] established the standard experimental procedures for vegetation trampling with a method that requires the structured trampling of previously undisturbed vegetation and comparison to a control site that was not trampled. However, this deliberate destruction of vegetation is not appropriate in highly sensitive ecosystems or where the vegetation of fragmented remnants may have already been damaged by trampling associated with existing recreational trails $[1,4]$. An alternate approach reported by Ballantyne and Pickering [1] overcomes that limitation of the Cole and Bayfield [13] method and avoids confounding effects by assuming that the vegetation would be uniform if not for the trampling associated with off-trail excursions associated with the presence of formal and/or informal recreational trails.

A problem was also identified in relation to how far from a recreational trail the vegetation should be sampled. Mason et al. [4] investigated trampling impacts at $7 \mathrm{~m}$ from trails, but Conradi et al. [65] sampled at $15 \mathrm{~m}$ from coastal trails to determine the structure of untrampled vegetation. In addition, a meta-analysis by Ballantyne and Pickering [13] reported that edge effect impacts from recreational trails could extend up to $20 \mathrm{~m}$ into the adjacent vegetation.

Many recreational trampling studies advocate the use of point intercept methods (PIM) to determine vegetation height $[4,13,14]$. While the PIM is considered an accurate and relatively unbiased method [66-68], Bråthen and Hagberg [69] show that the accuracy of the method is significantly influenced by the pin density, the number of plots sampled and variation in growth form of the vegetation. Further, the application of PIM can be time-consuming and a barrier to the collection of vegetation related ecological data [70,71].

Another technique used to investigate the structure of shrub vegetation is the cover pole method (CPM). However, the CPM suffers from many of the same problems as the PIM, in that CPM can be highly time-consuming, and surveys need to be conducted in a consistent fashion by skilled field operatives [72,73]. Failure to maintain a consistent research focus and technique for CPM sampling can confound the data, which negates the possibility of making comparisons between different studies or even between longitudinal sampling events in the same study [72,73].

An alternative to the PIM and the CPM is the sampling technique of Garden et al. [74], which was itself an adaptation of the methods established by MacArthur and MacArthur [75] and Haering and Fox [76]. That technique used a large sheet of material covered with $0.1 \mathrm{~m} \times 0.1 \mathrm{~m}$ grid cells to record three highly cross-correlated measures for the structure of the shrub layer vegetation (equivalent to the understory investigated in this case study). 
Informed by the studies highlighted in this section, this case study developed and field-tested the hybrid sampling method described in the following three sections to explore the impacts of recreational trampling on understory vegetation. The rationale for developing and documenting this hybrid sampling method was to provide a technique that environmentally-focused community volunteers (i.e., citizen scientists) could easily, accurately, and consistently apply to monitor the structure of remnant and replanted native vegetation incorporated into public open space as UGI.

\subsection{Sampling Understory Structure}

In summary, a different random start point was selected for each sampling event at each of the five sampling locations. In each year and for each location, sampling occurred along two sets of five parallel transects that were oriented perpendicular to the centerline of the trail with a $10 \mathrm{~m}$ spacing between the transects (Figure 2-Left). The structure of the understory was investigated in $1 \mathrm{~m} \times 1 \mathrm{~m}$ horizontal noncongruent quadrats at distances of $0 \mathrm{~m}$ (on the path), $0.1 \mathrm{~m}$ (next to the path), $1.5 \mathrm{~m}$ (from the edge of the path), $7 \mathrm{~m}, 15 \mathrm{~m}$, and $25 \mathrm{~m}$. The structure of the understory was sampled using a combined measure of the height and visual density of the vegetation in each quadrat using a $0.1 \mathrm{~m} \times 0.1 \mathrm{~m}$ vertical grid contained in a $1 \mathrm{~m} \times 1 \mathrm{~m}$ frame (Figure 2-Right). The vegetation was sampled with the grid positioned parallel to the path on the front edge of each horizontal quadrat (at previously specified distances from each trail). The understory was observed at a waist height of approximately $1 \mathrm{~m}$ either from on the trail or $2 \mathrm{~m}$ in front of the frame (trailside). Samplers recorded the highest row of the grid with native vegetation in every $0.1 \mathrm{~m} \times 0.1 \mathrm{~m}$ cell. This sampling method provides a semiquantitative combined measure of the height and visual density of shrub-dominated understory that ranges from 0 (shrub layer highly disturbed/absent) to 10 (uniformly tall and visually dense shrub layer).

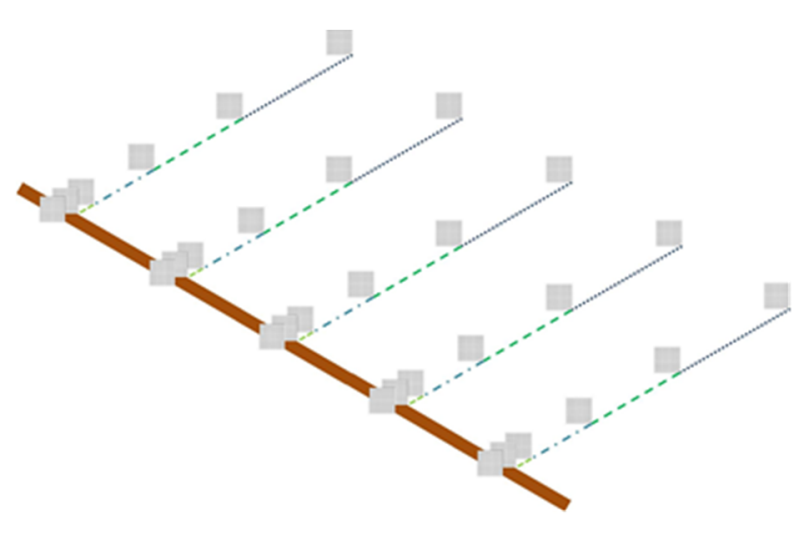

(a)

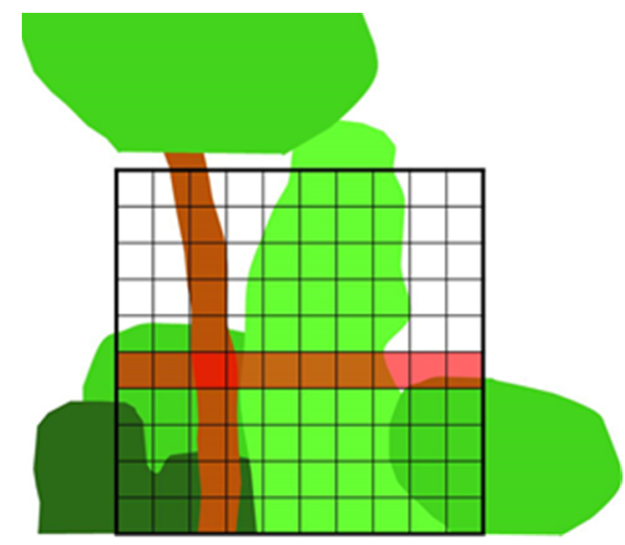

(b)

Figure 2. Arrangement of trail (brown) transects and quadrats for each sampling event at each sampling location (a) and measurement of the understory structure with the highest row shaded red (b).

In 2015 and 2016, two different groups of second-year tertiary-trained ecology students from Murdoch University, Western Australia, collected the data for this study on different days in our sampling window. In 2017 community-based volunteers (citizen scientists) replicated the data collected by the students. Consistent with established citizen science theory and practice [77-81], we consider both the novice student groups and the community volunteers to be citizen scientists and combine the analysis and reporting of their surveys.

\subsection{Establishing Control Plots}

This study also investigated the validity of using the $7 \mathrm{~m}, 15 \mathrm{~m}$, and $25 \mathrm{~m}$ sampling distances from recreational trails as control plots that could provide baseline data for the structure of the vegetation before trampling occurred. The assumption that underpins the establishment of these 
control plots is that the understory structure would be relatively uniform prior to being impacted by recreational trampling [1]. The trampling study of Mason et al. [3] that was set in protected areas with shrub-dominated vegetation in the southwest of Western Australia sampled along transects perpendicular to informal recreation trails to a distance of $7 \mathrm{~m}$ to determine the impact of recreational trampling. Conradi et al. [65] sampled at twice that distance $(15 \mathrm{~m})$ to establish control plots for their study of trampling associated with recreational trails through indigenous coastal grasslands. Based on a research gap identified from the literature and pre-sampling field observation, this study also sampled quadrats at $25 \mathrm{~m}$ to compare the suitability of the $7 \mathrm{~m}$ and $15 \mathrm{~m}$ distances as trampling study control plots in the shrub-dominated understory in urban remnants of Banksia woodland on the SCP. The selection of this sampling distance was subsequently supported by the meta-analysis of Ballantyne and Pickering [1], which found that edge effect impacts from recreational trails can extend can up to $20 \mathrm{~m}$ into the adjacent vegetation.

\subsection{Statistical Analyses}

Exploratory data analyses revealed that variation in path surfaces (i.e., concrete, compacted limestone dust, natural soil or wood-chip mulch) meant data for the $0 \mathrm{~m}$ (on path or trail) quadrat was highly confounded, so that data were excluded from the analyses reported in this study. For each replicate (sampling event), the understory structure at each of the five sampling locations was determined by calculating mean values for the highest row with native vegetation in every cell at each sampling distance from the trail (i.e., $0.1 \mathrm{~m}, 1.5 \mathrm{~m}, 7 \mathrm{~m}, 15 \mathrm{~m}$ and $25 \mathrm{~m}$ ) across each of the five transects. Annual means were then calculated for each distance from the trail based on the two replicates sampled at each of the five sampling locations each year. Under the Central Limit Theorem, it can be assumed that the annual means were normally distributed, which facilitated analyses based on the simple, robust parametric statistical tests of ANOVA (reported as the F statistic and $p$-value), paired $t$-testing (reported as the $t$ statistic and $p$-value), and least-squares linear regression (reported as the Pearson's $\mathrm{R}^{2}$ correlation value and $p$-value) [82]. The data for each sampling location is matched by distance from the trail, and it can be assumed that the understory had a uniform structure before it was fragmented and trampled [1]. As the data were matched by distance from the trail, paired $t$-tests were utilized for post hoc testing where an ANOVA provided evidence (i.e., $p$-value $<0.05)$ for a variation in the understory structure being investigated [83]. Scatter plots with trend lines based on the annual means for each sampling location and least-square linear regressions were performed to elucidate any change in the structure of the understory with distance from the trail at each location. The understory structure at $25 \mathrm{~m}$ from the fenced and unfenced recreational trails at the Murdoch site was explored via a paired $t$-test that compared the annual means and calculation of $95 \%$ confidence interval (95\% CI) for the baseline means (mean $\pm 95 \% \mathrm{CI}$ ). The $95 \% \mathrm{CI}$ was calculated for the $\alpha=0.05$ level of significance using $t_{2}=4.3027$ to counter the small sample size of $n=3[82,83]$.

\section{Results}

\subsection{Overall, Structure of the Understory}

Two-factor ANOVAs were performed to investigate differences in the understory structure between years and with distance from the recreational trails at each of the five sampling locations. No evidence was found to support a between-year variation in understory structure (i.e., $p$-values $>0.05$ ) at any of the five sampling locations between 2015 and 2017. That finding facilitated the calculation of benchmarking grand means across the three years for the five sampling locations. The annual and benchmarking means for the understory structure with distance from the recreation trails are shown in Table 1 . These findings can be interpreted through the least-square linear regressions and the graphical representation of the data provided in Figures 3 and 4 below. 
Table 1. Annual mean values for understory structure at each of the five sampling locations calculated from the two replicates of five transects sampled each year and baseline mean values for the understory structure calculated from the annual means. Reported values are the means of the semiquantitative measure of the highest row ( 0 to 10$)$ that had indigenous vegetation in every cell.

\begin{tabular}{|c|c|c|c|c|}
\hline \multicolumn{5}{|c|}{ Fenced Sampling Location at Murdoch } \\
\hline Distance from Trail & 2015 & 2016 & 2017 & Baseline Mean \\
\hline $0.1 \mathrm{~m}$ & 3.20 & 4.88 & 4.50 & 4.19 \\
\hline $1.5 \mathrm{~m}$ & 3.20 & 3.50 & 3.90 & 3.53 \\
\hline $7 \mathrm{~m}$ & 3.60 & 2.50 & 2.80 & 2.97 \\
\hline $15 \mathrm{~m}$ & 1.20 & 5.00 & 2.80 & 3.00 \\
\hline $25 \mathrm{~m}$ & 2.30 & 1.88 & 2.20 & 2.13 \\
\hline \multicolumn{5}{|c|}{ Unfenced sampling location at Murdoch } \\
\hline Distance from Trail & 2015 & 2016 & 2017 & Baseline Mean \\
\hline $0.1 \mathrm{~m}$ & 1.40 & 1.38 & 1.80 & 1.53 \\
\hline $1.5 \mathrm{~m}$ & 2.00 & 2.63 & 2.70 & 2.44 \\
\hline $7 \mathrm{~m}$ & 1.60 & 3.88 & 2.00 & 2.49 \\
\hline $15 \mathrm{~m}$ & 2.20 & 4.75 & 4.70 & 3.88 \\
\hline $25 \mathrm{~m}$ & 4.70 & 4.75 & 5.30 & 4.92 \\
\hline \multicolumn{5}{|c|}{ Banksia Woodland at Lake Claremont } \\
\hline Distance from Trail & 2015 & 2016 & 2017 & Baseline Mean \\
\hline $0.1 \mathrm{~m}$ & 0.50 & 1.88 & 1.30 & 1.23 \\
\hline $1.5 \mathrm{~m}$ & 1.20 & 2.25 & 1.90 & 1.78 \\
\hline $7 \mathrm{~m}$ & 0.30 & 1.00 & 1.80 & 1.03 \\
\hline $15 \mathrm{~m}$ & 1.60 & 0.25 & 6.90 & 2.92 \\
\hline $25 \mathrm{~m}$ & 0.90 & 1.00 & 3.20 & 1.70 \\
\hline \multicolumn{5}{|c|}{ Fenced sampling location at Claremont } \\
\hline Distance from Trail & 2015 & 2016 & 2017 & Baseline Mean \\
\hline $0.1 \mathrm{~m}$ & 0.90 & 0.88 & 2.00 & 1.26 \\
\hline $1.5 \mathrm{~m}$ & 1.50 & 1.50 & 4.50 & 2.50 \\
\hline $7 \mathrm{~m}$ & 2.20 & 1.50 & 2.70 & 2.13 \\
\hline $15 \mathrm{~m}$ & 0.70 & 3.25 & 2.00 & 1.98 \\
\hline $25 \mathrm{~m}$ & 1.00 & 1.50 & 1.30 & 1.27 \\
\hline \multicolumn{5}{|c|}{ Unfenced sampling location at Claremont } \\
\hline Distance from Trail & 2015 & 2016 & 2017 & Baseline Mean \\
\hline $0.1 \mathrm{~m}$ & 2.40 & 3.00 & 4.50 & 3.30 \\
\hline $1.5 \mathrm{~m}$ & 2.10 & 1.63 & 3.30 & 2.34 \\
\hline $7 \mathrm{~m}$ & 3.10 & 7.75 & 6.40 & 5.75 \\
\hline $15 \mathrm{~m}$ & 3.30 & 2.38 & 9.20 & 4.96 \\
\hline $25 \mathrm{~m}$ & 2.90 & 2.38 & 3.30 & 2.86 \\
\hline
\end{tabular}

As expected from the published literature, the two-factor ANOVA for the unfenced Banksia and eucalypt woodland at the Murdoch sampling location provided evidence of a variation in the understory structure with distance from the trail $(\mathrm{F}=9.860 ; p=0.0035)$. That finding is consistent with the regression analysis reported below and the graphical representations of the data provided in Figure 3. 
The two-factor ANOVA for the Banksia woodland sampling location at Lake Claremont also provided evidence for a variation in the understory structure with distance from the trail $(\mathrm{F}=3.259$; $p=0.0274)$. In contrast to the analyses for the unfenced sampling location at the Murdoch site, that result appears at odds with the outcome of the regression analysis reported below and the graphical representation of the data provided in Figure 4. However, further analysis suggests that the outcome of the two-factor ANOVA is a statistical artifact rather than an ecologically meaningful observation. With the data for that location matched across the annual means, potential differences in the understory structure with distance from the trail were investigated using paired $t$-tests. The only one-sided paired $t$-tests to generate a statistically significant outcome $(t=-5.810 ; p=0.0142)$ was between the understory structure next to the trail and at $1.5 \mathrm{~m}$ from the trail. That result suggests that the understory had better structure next to the trail than it did at $1.5 \mathrm{~m}$ from the trail. Closer inspection of the means provided in Table 1 and results reported in Figure 4 show that the data for the understory structure next to the trail and at $1.5 \mathrm{~m}$ are more tightly clustered than the highly variable data recorded further away from that trail. Hence the assertion that the outcomes of the two-factor ANOVA and paired $t$-tests for this location are statistical artifacts rather than ecologically meaningful observations.
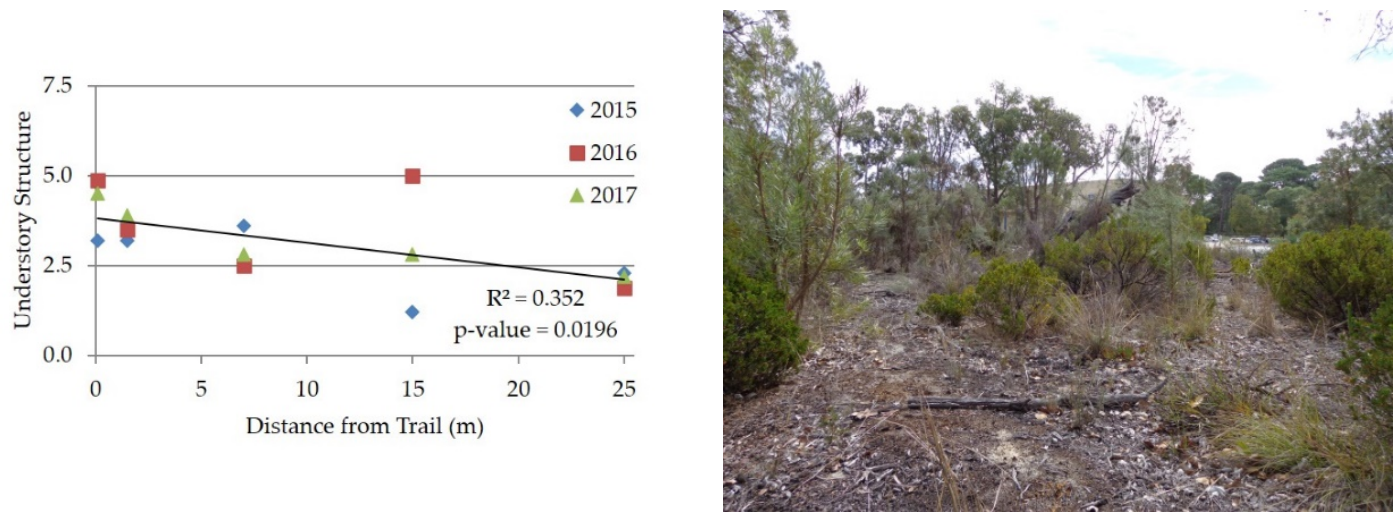

(a)
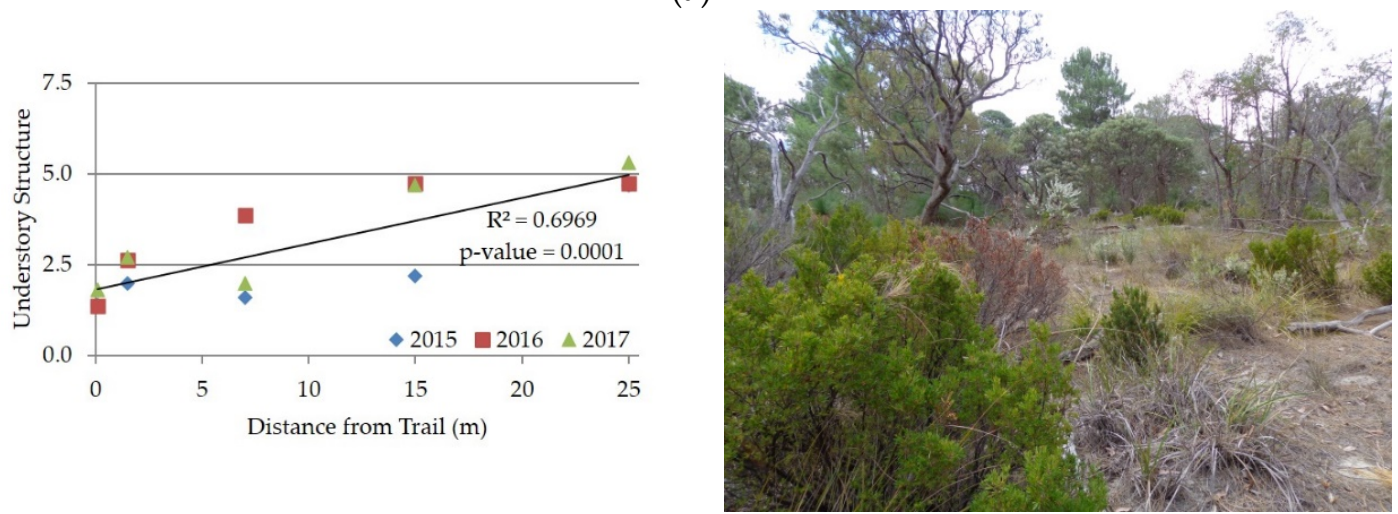

(b)

Figure 3. Change in the structure of the understory vegetation (highest complete row of $10 \times 0.01 \mathrm{~m} \times 0.01 \mathrm{~m}$ cells in a $1 \mathrm{~m} \times 1 \mathrm{~m}$ frame) with distance (in meters) from recreation trails in fenced (a) and unfenced (b) Banksia and eucalypt woodland at Murdoch University and contextual photographs of vegetation at both sampling location. Example photographs taken at waist height from the $15 \mathrm{~m}$ quadrat looking back along transects towards the recreation trail. 

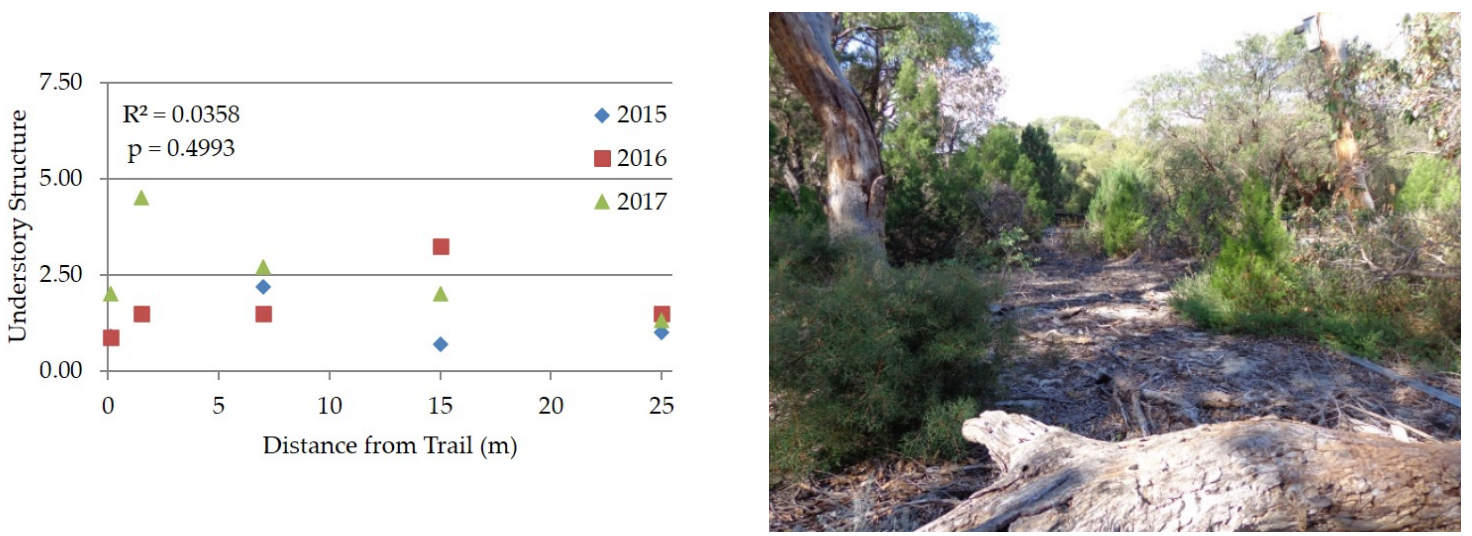

(a)
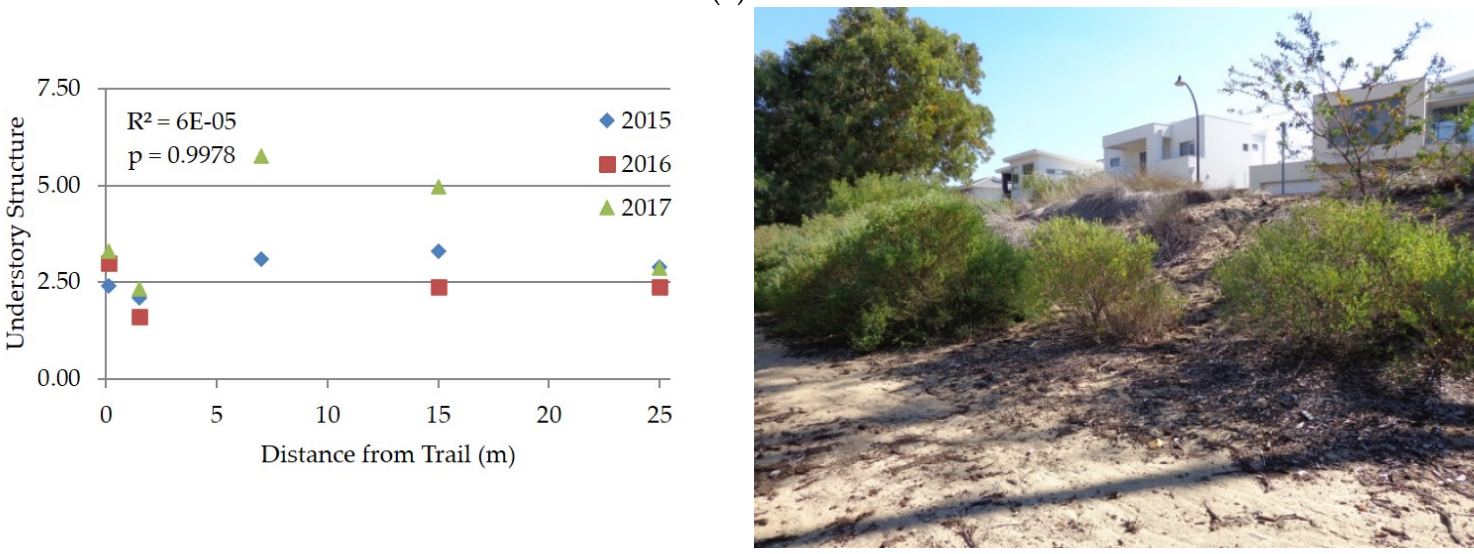

(b)
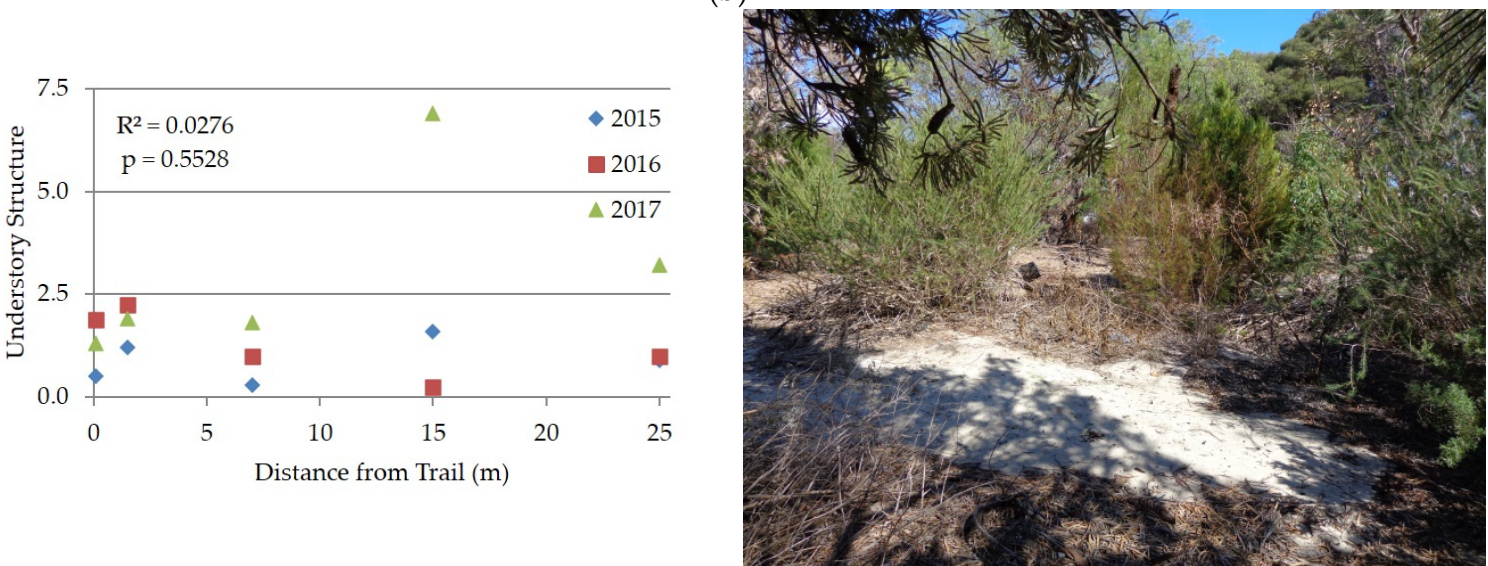

(c)

Figure 4. From $(\mathbf{a})-(\mathbf{c})$, the measured (highest totally covered row of $10 \times 0.01 \mathrm{~m} \times 0.01 \mathrm{~m}$ cells in a $1 \mathrm{~m} \times 1 \mathrm{~m}$ frame) and observed structure of the understory in the fenced Banksia and eucalyptus woodland, and the unfenced Banksia and eucalypt woodland, and the unfenced Banksia woodland at the Lake Claremont study site. As with Figure 3, example photographs taken at waist height from the $15 \mathrm{~m}$ quadrat looking back along the transect towards the trail.

A two-factor ANOVA based on the benchmarking means provided no evidence of a difference in the understory structure at each distance from the recreation trails across the five sampling locations. In the main, that finding is consistent with the regression analyses that suggest little variability in understory structure with distance from the trail at four of the five sampling locations. However, there was evidence for variation $(\mathrm{F}=3.707 ; p=0.0255)$ in the understory structure between the five sampling locations, and that finding was further supported by the outcomes of a single-factor ANOVA 
that compared the vegetation structure across the five sampling locations $(\mathrm{F}=3.919 ; p=0.0165)$. With the data across the sampling locations matched by distance from the recreation trails (the outcome of two-factor ANOVA), the statistically significant outcomes of the between sampling location paired $t$-test comparisons are reported in Table 2 . Theses analyses can be summarized as the overall understory structure along the transect at the:

- $\quad$ Fenced Murdoch sampling location being taller and visually denser than the replanted understory of the fenced location at Lake Claremont;

- Unfenced Murdoch sampling location being taller and visually denser than the replanted understory of the Lake Claremont Banksia woodland;

- Unfenced Claremont sampling location being taller and visually denser than the replanted understory of the Lake Claremont Banksia woodland; and

- Unfenced Claremont sampling location being taller and visually denser than the replanted understory of the fenced location at Lake Claremont.

Table 2. Overall structure of the understory along the transects and outcomes of paired t-tests comparing the baseline means for each of the five sampling locations. Reported values for the structure of the understory are mean values based on the semiquantitative measure of the highest row (0 to 10) with indigenous vegetation in every cell.

\begin{tabular}{ccccc}
\hline Sampling Locations & $\begin{array}{c}\text { Overall Structure } \\
\text { First Location }\end{array}$ & $\begin{array}{c}\text { Overall Structure } \\
\text { Second Location }\end{array}$ & t-Statistic & $p$-Value \\
\hline $\begin{array}{c}\text { Murdoch fenced and } \\
\text { Claremont fenced }\end{array}$ & 3.16 & 1.82 & 3.324 & 0.0146 \\
$\begin{array}{c}\text { Murdoch unfenced and } \\
\text { Claremont Banksia }\end{array}$ & 3.05 & 1.73 & 2.584 & 0.0305 \\
$\begin{array}{c}\text { Claremont Banksia and } \\
\text { Claremont unfenced }\end{array}$ & 1.73 & 3.842 & -2.967 & 0.0206 \\
$\begin{array}{c}\text { Claremont fenced and } \\
\text { Claremont unfenced }\end{array}$ & 1.82 & 3.842 & -3.018 & 0.0180 \\
\hline
\end{tabular}

\subsection{Impacts of Recreational Trampling}

As previously mentioned, this case study assumes the understory of the good to very good condition bushland at the two Murdoch sampling locations would have had a uniform structure prior to any recreational trampling. It was further assumed that the structure of the understory protected by the conservation fencing would remain uniform, while the height and density of the understory would decline adjacent to the recreational trail because of trampling. The structure of the replanted understory at Lake Claremont was unknown prior to this study.

Contrary to the assumptions of this study, the regression analysis (Figure 3a) for the fenced location at Murdoch provides evidence that the understory structure declined with increased distance from the fenced recreation trail. That finding is, however, at variance with the previously reported outcome of the two-factor ANOVA that provided no evidence for a difference in the understory structure along the transect at that location. Further, only about one third $\left(\mathrm{R}^{2}=0.35\right)$ of the variation in the understory structure suggested by the regression analysis was explained by moving along the transect away from the path. Possible explanations for these statistical outcomes that suggest a complex and variable nature for the understory structure at the fenced Murdoch sampling location are explored further in the discussion section below.

Consistent with the two-factor ANOVA reported in Section 4.1, the regression analysis (Figure 3b) provides evidence of a poorer structure of the understory adjacent to the unfenced recreational trail at Murdoch and a better structure of the understory with increased distance from the recreation trail, which is consistent with the assumptions of this study. 
Furthermore, consistent with the outcomes of the two-factor ANOVAs, the regression analyses (Figure $4 a, b$ ) for the structure of the replanted understory at the fenced and unfenced Banksia and eucalypt woodland sampling locations at Lake Claremont showed no variation in the understory structure with distance from the recreation trails. The regression analysis (Figure 4c) of the replanted understory of the Banksia woodland at Lake Claremont also provided no evidence of a change in structure along the transects. As previously mentioned, while that result appears to contradict the outcome of the two-factor ANOVA, the ANOVA outcome was more likely to be a statistical artifact than an insight into the understory structure.

As shown in Figure 4, it was detected both through the analyses and observations in the field that the understory structure in the Banksia and eucalypt woodland adjacent to the unfenced recreational trail at Lake Claremont (Figure $4 \mathrm{~b}$ ) was uniformly taller and denser than at the other two Claremont sampling locations. As reported in Table 2, those field observations are consistent with the outcomes of the ANOVA and post hoc paired $t$-test analyses. That observed and measured difference reflects the dominance of taller growing berry saltbush (Rhagodia baccata). Planted adjacent to the unfenced recreational trail, the berry saltbush had grown to the extent that it had become a tall monoculture at some points along the transects at that location.

\subsection{Establishing Control Plots}

As reported in the methods, it was an aim of this study to explore the strategy of establishing control plots in undisturbed or minimally disturbed vegetation at $7 \mathrm{~m}$ and $15 \mathrm{~m}$, as suggested by Mason et al. [3] and Conradi et al. [65], respectively, and at $25 \mathrm{~m}$ from the recreational trails. Unfortunately, the similarity of the vegetation along the transects at four of the five sampling locations and across the benchmark years (see Sections 4.1 and 4.2 above) meant that the position of control plots could not be statistically validated by this study.

An unexpected outcome was that the remnant understory at $25 \mathrm{~m}$ from the fenced recreational trail was significantly $(t=13.55 ; p=0.0027)$ lower and less dense $(2.13 \pm 0.54)$ than the understory at $25 \mathrm{~m}$ from the unfenced trail $(4.92 \pm 0.83)$ at the Murdoch study site. That variation in the understory at the Murdoch sampling locations was evident in the field.

\section{Discussion}

In summary, the analyses reported above revealed the following about the structure of the shrub-dominated understory vegetation at the Murdoch and Claremont sampling locations:

- Contrary to expectation, the understory structure at the fenced location at Murdoch declined along the transects by a statistically significant amount from a baseline value of 4.19 adjacent to the recreation trail to 2.19 at $25 \mathrm{~m}$ from the trail. However, statistically, only $35 \%$ of that variation can be explained by moving along the transect.

- Aligning with the published literature, the understory structure adjacent to the unfenced recreation trail at the Murdoch location improved a statistically significant amount from a baseline value of 1.53 adjacent to the trail to 4.92 at $25 \mathrm{~m}$ from the trail, with $75 \%$ of that improvement being explained by moving away from the trail.

- Unexpectedly, the structure of the understory $25 \mathrm{~m}$ from the fenced recreation trail at the Murdoch site was significantly lower and less dense (2.19) than the understory at $25 \mathrm{~m}$ from the fenced trail (4.29).

- In the main, the replanted understory at the Claremont sampling locations has a variable structure that is likely to need further time to consolidate and mature before detectable variations in structure could be measured.

- Of the five sampling locations, the replanted understory in the Banksia woodland remnant situated on the Quindalup Dune on the western side of Lake Claremont had the lowest and least dense (most disturbed) structure. 
Those findings demonstrate that the citizen science focused hybrid sampling method applied in this case study can detect anthropogenically induced variation in the structure of shrub-dominated understory vegetation. The ecological significance of the statistical analyses reported above is explored in this discussion by considering the post environmental histories of the two sampling sites, as summarized in Section 2. This study concludes by reflecting on the management implications of the findings, the limitations of this study, future research that should be pursued at both study sites, and more broadly scoped future research into the recreational trampling of remnant vegetation that is critical for delivering the environmental services and human connections to nature that are provided by UGI.

\subsection{Understory of Murdoch University Study Site}

It was surprising to observe and statistically confirm the observed difference in the structure of the understory at $25 \mathrm{~m}$ from the recreation trails at the Murdoch site. Given the published and previously stated assumptions that the remnant vegetation at that distance from the trails should have a uniform undisturbed structure, it was unexpected that the vegetation behind the conservation fence was lower or visually less dense than the vegetation at $25 \mathrm{~m}$ from the unfenced trail. Based on this single study, we can only speculate that the disturbance of the understory adjacent to the fenced trail arose from the construction of the Murdoch campus access road and/or the adjacent secondary school. Alternatively, the understory structure at that location may be degraded due to edge effects $[59,84]$. However, based on the work of Ballantyne and Pickering [1], we would expect to see an improvement in the structure of the understory to $20 \mathrm{~m}$ should recreational trampling associated with the trail infrastructure be impacting the vegetation, which is the opposite of the decrease in the quality of the understory structure with increased distance from the fenced recreational trail.

Given the three alternatives outlined above, we postulate that our measurement of the understory structure at the fenced Murdoch sampling location demonstrates that while the Banksia and eucalypt woodland may have been degraded by the construction of the road and school, over the past 25 years, the shrub-dominated understorey has been uniformly recovering. As reported by Santoro et al. [17], the installation of the conservation fencing may have provided a degree of protection from trampling that would aid the reestablishment and recovery of the understory. However, using the easily implemented hybrid assessment method described in this article, a longitudinal study could reveal if the understory is recovering or degrading further from edge effects other than off-trail trampling at that location.

Consistent with the published literature $[1,4,17,65]$, we further postulate that before the installation of the unfenced walking trail, the remnant vegetation at that location would have been uniform and representative of the Banksia and eucalypt woodland that grew across the Spearwood Dunes prior to European colonization. The lower and less dense understory structure and the graduated improvement in the structure of the understory along the transect moving away from the trail fits with the description of recreational trail impacts reported in the experimental work of Santoro et al. [17] and Ballantyne et al. [85] and in the systematic literature review of Ballantyne and Pickering [1]. Further, the shrub-dominated understory at this sampling location was found to be taller and denser at $25 \mathrm{~m}$ from the trail, which is beyond the impact zone of $20 \mathrm{~m}$ reported by Ballantyne and Pickering [1].

\subsection{Understory of Lake Claremont Study Site}

While the replanted understory at the Lake Claremont study site was too variable to detect evidence of recreational trampling impacts, the sampling method reported in this case study did detect a difference in the understory structure of the Banksia and eucalypt woodland at the unfenced sampling location that was observed in the field. Evidence of off-trail trampling impacts was also observed at the other two sampling locations at Lake Claremont. We believe that the implementation of a longitudinal study using the methods of this study could monitor the improvement of the understory at the fenced location because of natural regeneration and restoration plantings by the Friends of Lake Claremont. 
Additionally, we believe that should the woodland at the other two Claremont sampling locations remain unfenced, then longitudinal monitoring will demonstrate that the structure of the understory improves more slowly than the fenced location or that it may even remain in a degraded condition with no improvement.

\subsection{Management Implications}

This study demonstrates that the reported novel hybrid method provides a simple, effective, and efficient method by which citizen scientists and land managers can rapidly assess how the trampling associated with urban recreation trails impacts the structure of understory vegetation, especially in good condition shrub-dominated habitat. The implementation of the method reported in this article would facilitate longitudinal monitoring by citizen scientists that could detect local ecosystem-scale variations in understory structure caused by the impacts of recreational trampling. Further, we hypothesize that our rapid assessment method is also suitable for quantitatively monitoring the longitudinal improvement or otherwise of shrub-dominated understory vegetation in degraded urban nature spaces that are undergoing restoration.

\subsection{Limitations and Further Research}

A limitation of this study is that it was conducted in two small urban remnants of Banksia woodlands that could be expected to have similar understory vegetation. Another limitation is that the geographical area of remnant bushland within those sites that was suitable for monitoring (i.e., not impacted by roads or other trails) limited the number of sampling locations and the number of replicate transects that could be surveyed at each location. Further, based on this relatively short-term study, we are unable to determine definitively whether the disturbance to the understory at the fenced Murdoch sampling location arose from the construction of the access road and/or secondary school or if it reflects the degradation of the indigenous vegetation due to the edge effects.

Having demonstrated the suitability of the sampling method for community-based citizen scientists wishing to sample or monitor the structure of shrub-dominated understory in remnant vegetation in urban areas, additional research could be undertaken to explore the applicability of this technique in other types of vegetation and understory, grassland for example. We hope that the publication of this article will facilitate the establishment of ongoing programs to monitor the remnant and replanted understory at Murdoch University, Lake Claremont, and other urban and rural green spaces and natural spaces on the Swan Coastal Plain. We envisage that the method specified in this article could also provide community representatives and land managers with a semiquantitative alternative to visual assessments of vegetation density and fuel loads that are currently undertaken in fire-prone landscapes [86-88].

Ballantyne and Pickering [1] identify several aspects of pedestrian trampling associated with trail infrastructure that require additional research, with which we concur based on the insights gained during this study. Those recommendations for further research, which we envisage could involve or be undertaken by citizen scientists applying the methods described in this article, include investigation of:

- Larger scale impacts at greater distances from the trail infrastructure (e.g., $20 \mathrm{~m}$ to $25 \mathrm{~m}$ ).

- Differences between impacts arising from formal and informal trails.

- Longitudinal studies of recreational trail impact instead of a reliance on a one-off or short-term snapshot studies.

- Longitudinal studies of ecosystem recovery after trails have been closed.

- How trail impacts may interact with other anthropogenic stressors (e.g., climate change, mowing, grading and trail maintenance). 


\section{Conclusions}

The field and statistical techniques presented in this article provide a quick, easy, and reproducible method that community-based citizen scientists and/or land managers can employ to assess the structure of shrub-dominated understory vegetation in urban remnants and to monitor the impact of trampling arising from excursions away from formal and informal trails. The hybrid sampling method promoted through this article also provides an effective and efficient data collection method that would be applicable to recreation ecology research into any of these aspects of the trampling associated with trail infrastructure and fire ecology studies that explore vegetation density and fuel loads in shrub-dominated understory and heathland communities.

Author Contributions: Conceptualization and methodology, G.D.S. and P.G.L.; E.G., G.D.S. and J.P.; writing-original draft preparation, E.G. and G.D.S.; writing-review and editing, G.D.S., J.P., E.G. and P.G.L.; project administration, G.D.S.; supervision, G.D.S. and P.G.L. All authors have read and agreed to the published version of the manuscript.

Funding: This research received no external funding.

Acknowledgments: G.S. thanks the Friends of Lake Claremont (FOLC) Board for their ongoing cooperation, encouragement, and support for his research G.S. We thank the Murdoch University ENV241 Ecology students and the community volunteers for their efforts in collecting the data that informed this case study. We also thank the FOLC volunteers for their years of effort in revegetating the degraded native vegetation at Lake Claremont. We thank Rachel Standish for her support in selecting this project as one of the real-world learning experiences for ENV241 in 2015 and 2016 and David Newsome for his insights on conducting trampling studies during the study design phase and his comments on an early draft of this article. Finally, we thank the Editors of Urban Science for their assistance in the publication of this article and the three anonymous reviewers whose insightful comments significantly enhanced the quality of our manuscript.

Conflicts of Interest: The authors declare no conflict of interest.

\section{Appendix A}

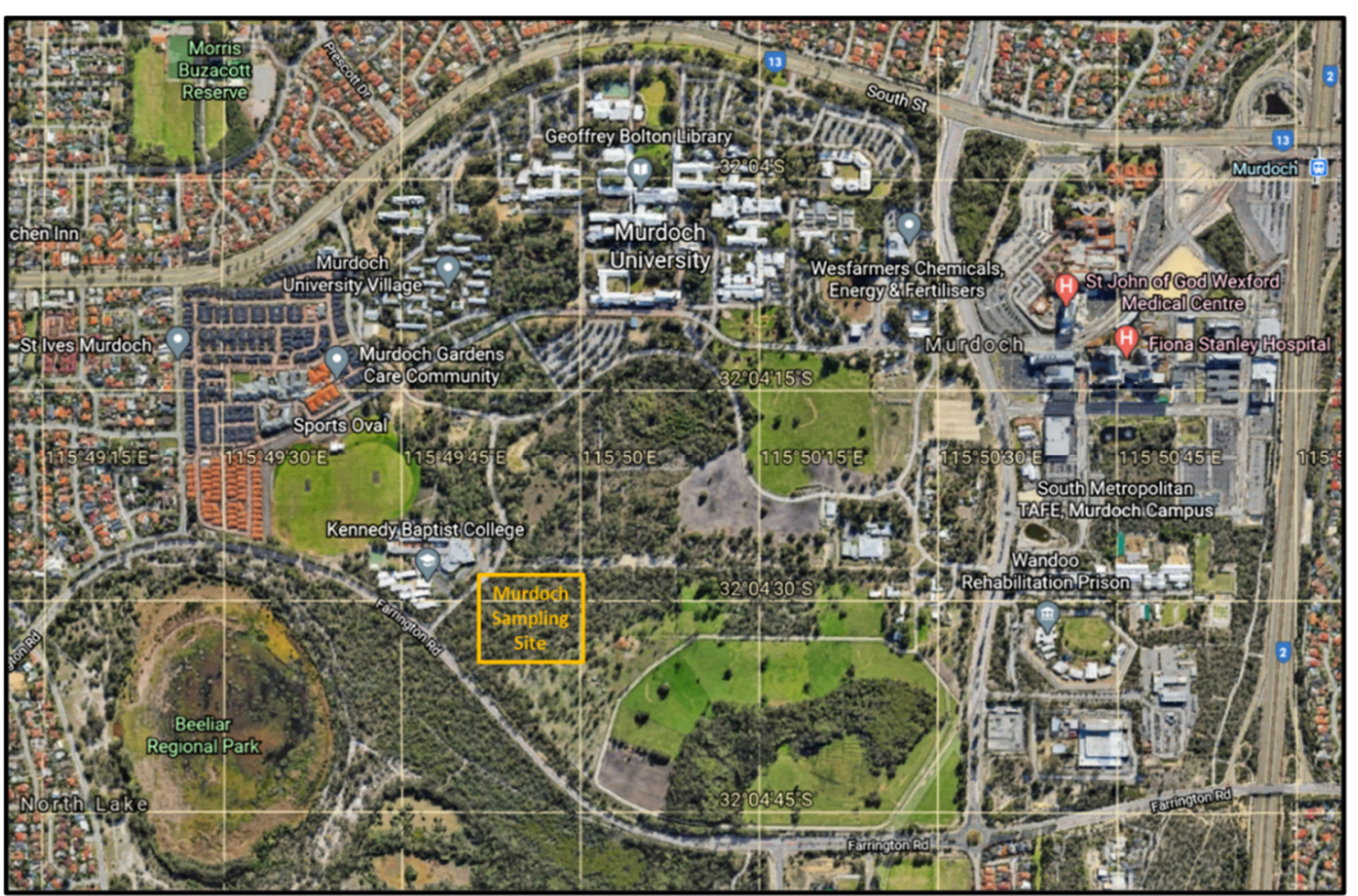

Figure A1. Location of the sampling site at Murdoch University (Source: Google Earth [89]). 


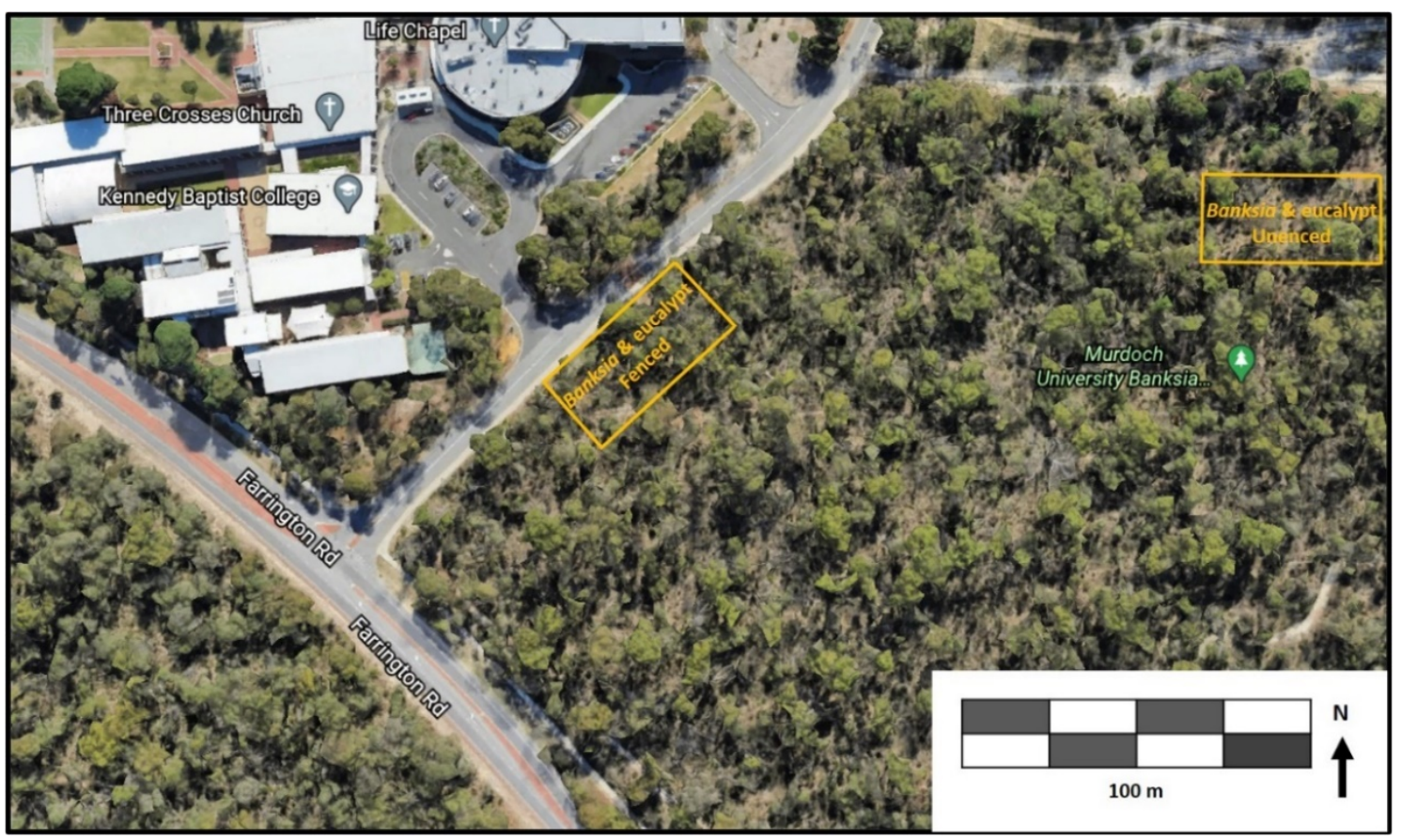

Figure A2. Locale of the transects for sampling understory structure adjacent to the fenced and unfenced recreational trails at Murdoch University (source: Google Earth [89]).

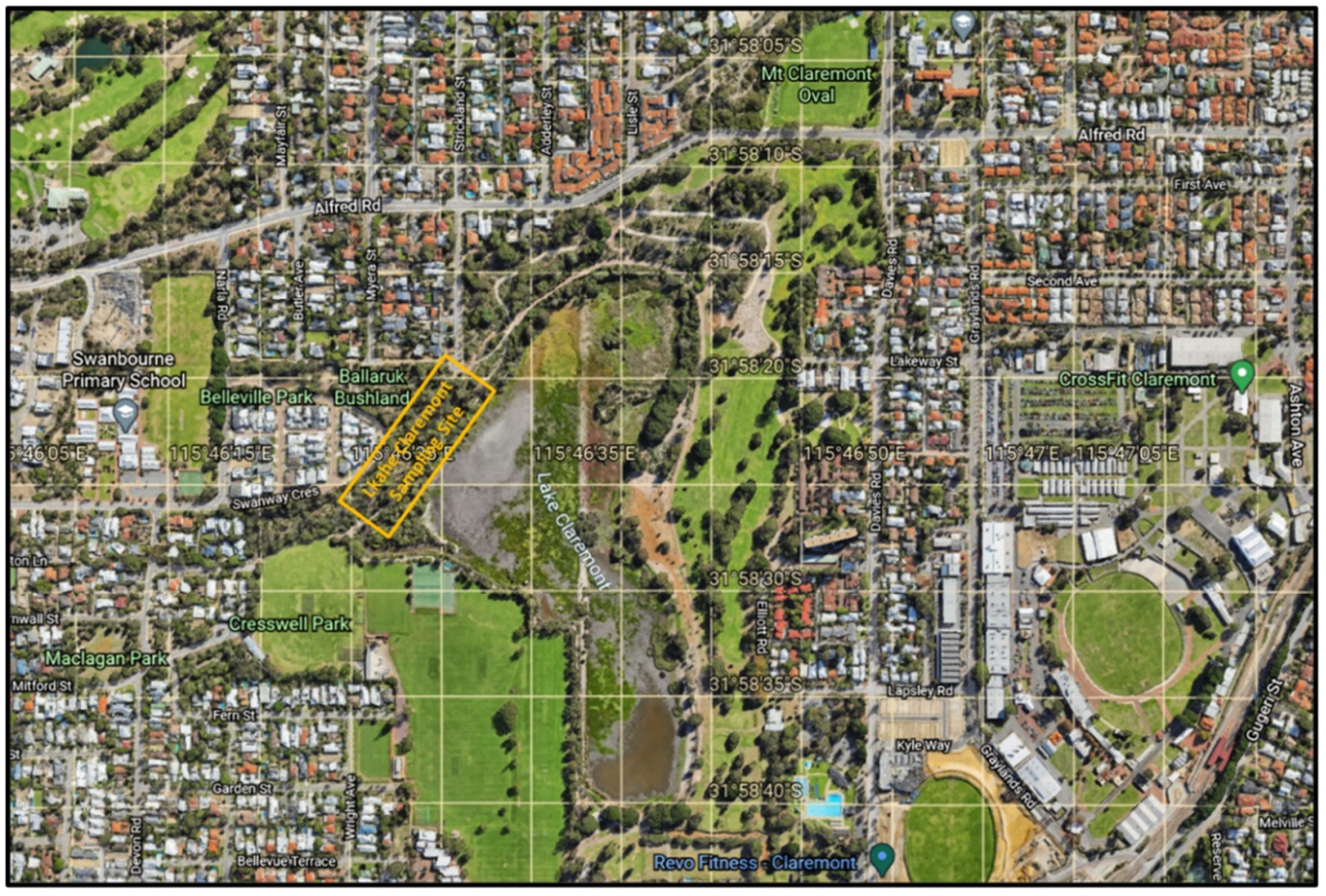

Figure A3. Location of the sampling site at Lake Claremont (source: Google Earth [90]). 


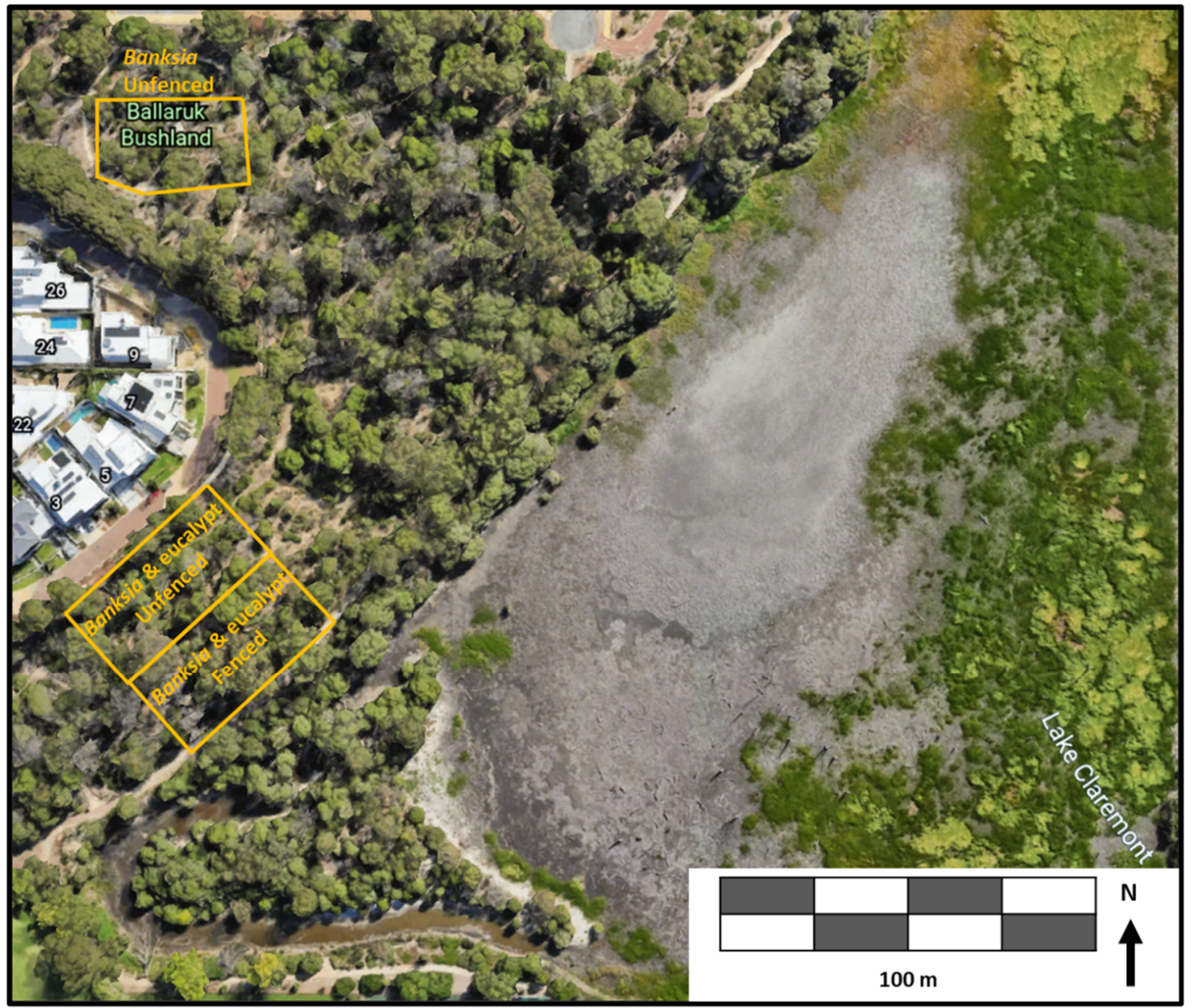

Figure A4. Locale of the transects for sampling understory structure adjacent to the fenced and unfenced recreational trails at Lake Claremont (source: Google Earth [90]).

\section{References}

1. Ballantyne, M.; Pickering, C.M. The impacts of trail infrastructure on vegetation and soils: Current literature and future directions. J. Environ. Manag. 2015, 164, 53-64. [CrossRef] [PubMed]

2. Ignatieva, M.; Haase, D.; Dushkova, D.; Haase, A. Lawns in Cities: From a Globalised Urban Green SPACE phenomenon to Sustainable Nature-Based Solutions. Land 2020, 9, 73. [CrossRef]

3. Kostrakiewicz-Gierałt, K.; Pliszko, A.; Gmyrek-Gołab, K. The effect of visitors on the properties of vegetation of calcareous grasslands in the context of width and distances from tourist trails. Sustainability 2020, $12,454$. [CrossRef]

4. Mason, S.; Newsome, D.; Moore, S.; Admiraal, R. Recreational trampling negatively impacts vegetation structure of an Australian biodiversity hotspot. Biodivers. Conserv. 2015, 24, 2685-2707. [CrossRef]

5. Ballantyne, M.; Gudes, O.; Pickering, C.M. Recreational trails are an important cause of fragmentation in endangered urban forests: A case-study from Australia. Landsc. Urban. Plan. 2014, 130, 112-124. [CrossRef]

6. Parker, J.; Simpson, G.D. A theoretical framework for bolstering human-nature connections and urban resilience via green infrastructure. Land 2020, 9, 252. [CrossRef]

7. Simpson, G.; Newsome, D. Environmental history of an urban wetland: From degraded colonial resource to nature conservation area. Geo Geogr. Environ. 2017, 4, e00030. [CrossRef]

8. de la Barrera, F.; Henrìquez, C.; Coulombié, F.; Dobbs, C.; Salazar, A. Periurbanization and conservation pressures over remnants of native vegetation: Impact on ecosystem services for a Latin-American capital city. Chang. Adapt. Socio-Ecol. Syst. 2019, 4, 21-32. [CrossRef] 
9. Fernández, I.C.; Wu, J.; Simonetti, J.A. The urban matrix matters: Quantifying the effects of surrounding urban vegetation on natural habitat remnants in Santiago de Chile. Landsc. Urban. Plan. 2019, 187, 181-190. [CrossRef]

10. Newsome, D.; Moore, S.A.; Dowling, R.K. Natural Area Tourism: Ecology, Impacts and Management; Channel View Publications: Bristol, UK, 2013; Volume 58.

11. Marasinghe, S.; Simpson, G.D.; Newsome, D.; Perera, P. Scoping recreational disturbance of shorebirds to inform the agenda for research and management in Tropical Asia. Trop. Life Sci. Res. 2020, 31, 51-78. [CrossRef]

12. Liddle, M.J. A selective review of the ecological effects of human trampling on natural ecosystems. Biol. Conserv. 1975, 7, 17-36. [CrossRef]

13. Cole, D.N.; Bayfield, N.G. Recreational trampling of vegetation: Standard experimental produces. Biol. Conserv. 1993, 63, 209-215. [CrossRef]

14. Phillips, N.; Newsome, D. Understanding the impacts of recreation in Australian protected areas: Quantifying damage caused by horse riding in D’Entrecasteaux National Park, Western Australia. Pac. Conserv. Biol. 2002, 7, 256-273. [CrossRef]

15. Pickering, C.M.; Hill, W. Impacts of recreation and tourism on plant biodiversity and vegetation in protected areas in Australia. J. Environ. Manag. 2007, 85, 791-800. [CrossRef] [PubMed]

16. Whinam, J.; Cannell, E.J.; Kirkpatrick, J.B.; Comfort, M. Studies on the potential impact of recreational horseriding on some alpine environments of the Central Plateau. Tasman. J. Environ. Manag. 1994, 40, 103-117. [CrossRef]

17. Santoro, R.; Jucker, T.; Prisco, I.; Carboni, M.; Battisti, C.; Acosta, A.T. Effects of trampling limitation on coastal dune plant communities. Environ. Manag. 2012, 49, 534-542. [CrossRef]

18. Parker, J.; Simpson, G.D.; Miller, J.E. Nature-based solutions forming urban intervention approaches to anthropogenic climate change: A quantitative literature review. Sustainability 2020, 12, 7439. [CrossRef]

19. Patroni, J.; Day, A.; Lee, D.; Chan, J.K.L.; Kerr, D.; Newsome, D.; Simpson, G.D. Looking for evidence that place of residence influenced visitor attitudes to feeding wild dolphins. Tour. Hosp. Manag. 2018, 24, 87-105. [CrossRef]

20. Pyle, R.M. The Thunder Tree: Lessons from an Urban. Wildland; The Lyons Press: New York, NY, USA, 1993.

21. Miller, J.R. Biodiversity conservation and the extinction of experience. Trends Ecol. Evol. 2005, 20, 430-434. [CrossRef]

22. Beard, J.S. Definition and location of Banksia woodlands. J. R. Soc. West. Aust. 1989, 71, 85-86.

23. Hercock, M.J. Appreciating the biodiversity of remnant bushland: An 'architectural' approach. Environmentalist 1997, 17, 249-258. [CrossRef]

24. How, R.A.; Dell, J. Ground vertebrate fauna of Perth's vegetation remnants: Impact of 170 years of urbanization. Pac. Conserv. Biol. 2000, 6, 198-217. [CrossRef]

25. Myers, N.; Mittermeier, R.A.; Mittermeier, C.G.; Da Fonseca, G.A.; Kent, J. Biodiversity hotspots for conservation priorities. Nature 2000, 403, 853-858. [CrossRef] [PubMed]

26. Pauli, N.; Boruff, B. Natural Environments, Ecosystem Services and Green Infrastructure: Planning for Perth's 'Green' Matrix. In Planning Boomtown and Beyond; Sharon Biermann, S., Olaru, D., Paül, V., Eds.; UWA Publishing: Perth, Australia, 2016; pp. 238-276.

27. Crosti, R.; Dixon, K.W.; Ladd, P.C.; Yates, C.J. Changes in the structure and species dominance in vegetation over 60 years in an urban bushland remnant. Pac. Conserv. Biol. 2007, 13, 158-170. [CrossRef]

28. Eakin-Busher, E.L.; Ladd, P.G.; Fontaine, J.B.; Standish, R.J. Mating strategies dictate the importance of insect visits to native plants in urban fragments. Aust. J. Bot. 2020, 68, 26-36. [CrossRef]

29. Nguyen, T.T.; Barber, P.; Harper, R.; Linh, T.V.K.; Dell, B. Vegetation trends associated with urban development: The role of golf courses. PLoS ONE 2020, 15, e228090. [CrossRef] [PubMed]

30. Simpson, G.D.; Parker, J. Data on Peer-Reviewed papers about green infrastructure, urban nature, and city liveability. Data 2018, 3, 51. [CrossRef]

31. Jones, C.; Newsome, D. Perth (Australia) as one of the world's most liveable cities: A perspective on society, sustainability and environment. Int. J. Tour. Cities 2015, 1, 18-35. [CrossRef] 
32. Parker, J.; Simpson, G.D. Public green infrastructure contributes to city livability: A systematic quantitative review. Land 2018, 7, 161. [CrossRef]

33. Simpson, G.D.; Parker, J. Data for an importance-performance analysis (IPA) of a public green infrastructure and urban nature space in Perth, Western Australia. Data 2018, 3, 69. [CrossRef]

34. Parker, J.; Simpson, G.D. Visitor satisfaction with a public green infrastructure and urban nature space in Perth, Western Australia. Land 2018, 7, 159. [CrossRef]

35. Frydenberg, J. (Minister for the Environment and Energy). Amendment to the List of Threatened Species, Threatened Ecological Communities and Key Threatening Processes under Sections 178, 181 and 183 of the Environment Protection and Biodiversity Conservation Act. 1999; Australian Government, Federal Register of Legislation: Canberra, Australia, 2016. Available online: https://www.legislation.gov.au/Details/F2016L01442 (accessed on 22 October 2020).

36. Threatened Species Scientific Committee. Approved Conservation Advice (Incorporating Listing Advice) for the Banksia Woodlands of the Swan Coastal Plain Ecological Community; Australian Government, Department of the Environment and Energy: Canberra, Australia, 2016. Available online: http://www.environment.gov.au/bio diversity/threatened/communities/pubs/131-conservation-advice.pdf (accessed on 22 October 2020).

37. Keighery, B. Bushland Plant. Survey, A Guide to Plant. Community Survey for the Community; Wildflower Society of Western Australia (Incorporated): Nedlands, Australia, 1994.

38. Casson, N.; Downes, S.; Harris, A. Native Vegetation Condition Assessment and Monitoring Manual for Western Australia; Western Australian Department of Environment and Conservation: Perth, Australia, 2009. Available online: https:/www.dpaw.wa.gov.au/images/documents/plants-animals/monitoring/native_veget ation_condition_manual_full.pdf (accessed on 20 October 2020).

39. Wyrwoll, K.H.; Turner, B.L.; Findlater, P. On the Origins, Geomorphology and Soils on the Sandplains of South.-Western Australia. Plant. Life on the Sandplains in Southwest Australia, A Global Biodiversity Hotspot; University of Western Australia Publishing: Crawley, Austrlia, 2014; p. 323.

40. Laliberte, E.; Turner, B.L.; Costes, T.; Pearse, S.J.; Wyrwoll, K.H.; Zemunik, G.; Lambers, H. Experimental assessment of nutrient limitation along a 2-million-year dune chronosequence in the south-western Australia biodiversity hotspot. J. Ecol. 2012, 100, 631-642. [CrossRef]

41. Brooke, B.P.; Olley, J.M.; Pietsch, T.; Playford, P.E.; Haines, P.W.; Murray-Wallace, C.V.; Woodroffe, C.D. Chronology of Quaternary coastal aeolianite deposition and the drowned shorelines of southwestern Western Australia-a reappraisal. Quat. Sci. Rev. 2014, 93, 106-124. [CrossRef]

42. Australia Bureau of Meteorology. Climate Statistics for Australian Locations: Summary Statistics Perth Metro. Available online: http://www.bom.gov.au/climate/averages/tables/cw_009225.shtml (accessed on 22 October 2020).

43. Simpson, G.D. Cracking the niche: An Investigation into the Impact of Climatic Variables on Germination of the Rare Shrub Verticordia staminosa Subspecies staminosa (Myrtaceae). Honours Thesis, Murdoch University, Perth, Australia, 2011. Available online: https://researchrepository.murdoch.edu.au/id/eprint/8485/ (accessed on 22 October 2020).

44. Environmental Protection Authority. Guidance Statement No. 51: Terrestrial Flora and Vegetation Surveys for Environmental Impact Assessment in Western Australia. Available online: http://www.epa.wa.gov.au/ep adoclib/1839_gs51.pdf (accessed on 20 October 2020).

45. Groom, P.K.; Froend, R.H.; Mattiske, E.M.; Gurner, R.P. Long-term changes in vigour and distribution of Banksia and Melaleuca overstorey species on the Swan Coastal Plain. J. R. Soc. West. Aust. 2001, 84, 63-69.

46. Bolton, G.; Gregory, J. Claremont: A History; University of Western Australia Press: Nedlands, Australia, 1999.

47. City of Cockburn. Cockburn History: Thematic Framework; City of Cockburn: Cockburn, Australia, 2017. Available online: https://www.cockburn.wa.gov.au/getattachment/d0f83db0-a0c9-437b-9db5-0c599731cfd8/ attachment.aspx (accessed on 25 October 2020).

48. Bolton, G. It Had Better be A Good One: The First Ten Years of Murdoch University; Murdoch University: Perth, Australia, 1985. Available online: https://researchrepository.murdoch.edu.au/id/eprint/51558 (accessed on 25 October 2020). 
49. Environmental Protection Authority. Proposed Farrington Road Duplication Murdoch Drive to West of Bibra Drive. Environmental Protection Authority [Bulletin 517]; Environmental Protection Authority: Perth, Australia, 1991. Available online: https://epa.wa.gov.au/sites/default/files/EPA_Report/480_B517.pdf (accessed on 25 October 2020).

50. Murdoch University. Senate Meeting Minutes 28 June 1993. Available online: http://senate.murdoch.edu.au/ 1993/280693mins.html (accessed on 25 October 2020).

51. Kennedy Baptist College: The Kennedy Story. Available online: https://www.kennedy.wa.edu.au/about/thekennedy-story/ (accessed on 25 October 2020).

52. Murdoch University. News: University Revamps Nature Trails. Available online: https://www.murdoch.ed u.au/news/articles/university-revamps-nature-trails (accessed on 25 October 2020).

53. Haynes, B.T.; Lantzke, I.R.; Lantzke, P.M. Lake Claremont Policy: Revised 1998; Town of Claremont: Claremont, Australia, 1998. Available online: https://www.claremont.wa.gov.au/MediaLibrary/TownOfClaremont/Doc uments/Lake-Claremont-Policy-(revised-1998).pdf (accessed on 25 October 2020).

54. Lantzke, I.R.; Lantzke, P.M. Review of Environmental Developments and Changes at Lake Claremont since Adoption of the 1992 Management Plan; Town of Claremont: Claremont, Australia, 1998.

55. Head, A.; Simpson, G.D.; Brand, S. Lake Claremont Management Plan. 2016-2021; Town of Claremont: Claremont, Australia, 2016. Available online: https://www.claremont.wa.gov.au/MediaLibrary/TownOfClare mont/Documents/Lake-Claremont-Mgt-Plan-2016-Final-May-17.pdf (accessed on 25 October 2020).

56. Ballantyne, M.; Pickering, C.M. Recreational trails as a source of negative impacts on the persistence of keystone species and facilitation. J. Environ. Manag. 2015, 159, 48-57. [CrossRef] [PubMed]

57. Bernhardt-Römermann, M.; Baeten, L.; Craven, D.; De Frenne, P.; Hédl, R.; Lenoir, J.; Bert, D.; Brunet, J.; Chudomelová, M.; Decocq, G.; et al. Drivers of temporal changes in temperate forest plant diversity vary across spatial scales. Glob. Chang. Biol. 2015, 21, 3726-3737. [CrossRef] [PubMed]

58. Pettit, N.E.; Ladd, P.G.; Froend, R. Passive clearing of native vegetation: Livestock damage to remnant jarrah (Eucalyptus marginata) woodlands in Western Australia. J. R. Soc. West. Aust. 1998, 81, 95-106.

59. Villaseñor, N.R.; Blanchard, W.; Lindenmayer, D.B. Decline of forest structural elements across forest-urban interfaces is stronger with high rather than low residential density. Basic Appl. Ecol. 2016, 17, 418-427. [CrossRef]

60. Newman, B.J.; Ladd, P.; Brundrett, M.; Dixon, K.W. Effects of habitat fragmentation on plant reproductive success and population viability at the landscape and habitat scale. Biol. Conserv. 2013, 159, 16-23. [CrossRef]

61. Cramer, V.A.; Standish, R.J.; Hobbs, R.J. Prospects for the recovery of native vegetation in western Australian old fields. In Old Fields: Dynamics and Restoration of Abandoned Farmland; Cramer, V.A., Hobbs, R.J., Eds.; Island Press: Washington, DC, USA, 2007; pp. 286-306.

62. Pettit, N.E.; Froend, R.H. Regeneration of degraded woodland remnants after relief from livestock grazing. J. R. Soc. West. Aust. 2000, 83, 65-74.

63. Pettit, N.E.; Froend, R.H. Long-term changes in the vegetation after the cessation of livestock grazing in Eucalyptus marginata (jarrah) woodland remnants. Austral. Ecol. 2001, 26, 22-31.

64. Standish, R.J.; Daws, M.I.; Gove, A.D.; Didham, R.K.; Grigg, A.H.; Koch, J.M.; Hobbs, R.J. Long-term data suggest jarrah-forest establishment at restored mine sites is resistant to climate variability. J. Ecol. 2015, 103, 78-89. [CrossRef]

65. Conradi, T.; Strobl, K.; Wurfer, A.L.; Kollmann, J. Impacts of visitor trampling on the taxonomic and functional community structure of calcareous grassland. Appl. Veg. Sci. 2015, 18, 359-367. [CrossRef]

66. Herrick, J.E.; Schuman, G.E.; Rango, A. Monitoring ecological processes for restoration projects. J. Nat. Conserv. 2006, 14, 161-171. [CrossRef]

67. Jonasson, S. Evaluation of the point intercept method for the estimation of plant biomass. Oikos 1988, 52, 101-106. [CrossRef]

68. White, A.; Foulkes, J.N.; Sparrow, B.D.; Lowe, A.J. Biodiversity monitoring in the Australian rangelands. In Biodiversity Monitoring in Australia; Lindenmayer, D., Gibbons, P., Eds.; CSIRO Publishing: Melbourne, Australia, 2013; p. 187.

69. Bråthen, K.A.; Hagberg, O. More efficient estimation of plant biomass. J. Veg. Sci. 2004, 15, 653-660. [CrossRef] 
70. Mamet, S.D.; Young, N.; Chun, K.P.; Johnstone, J. What is the most efficient and effective method for long-term monitoring of alpine tundra vegetation? Arct. Sci. 2016, 2, 127-141. [CrossRef]

71. Tokmakoff, A.; Sparrow, B.; Turner, D.; Lowe, A. AusPlots Rangelands field data collection and publication: Infrastructure for ecological monitoring. Future Gener. Comput. Syst. 2016, 56, 537-549. [CrossRef]

72. Toledo, D.P.; Abbott, L.B.; Herrick, J.E. Cover Pole Design for Easy Transport, Assembly, and Field Use. J. Wildl. Manag. 2008, 72, 564-567. [CrossRef]

73. Toledo, D.P.; Herrick, J.E.; Abbott, L.B. A Comparison of Cover Pole with Standard Vegetation Monitoring Methods. J. Wildl. Manag. 2010, 74, 600-604. [CrossRef]

74. Garden, J.G.; McAlpine, C.A.; Possingham, H.P.; Jones, D.N. Habitat structure is more important than vegetation composition for local-level management of native terrestrial reptile and small mammal species living in urban remnants: A case study from Brisbane, Australia. Austral. Ecol. 2007, 32, 669-685. [CrossRef] [PubMed]

75. MacArthur, R.H.; MacArthur, J.W. On bird species diversity. Ecology 1961, 42, 594-598. [CrossRef]

76. Haering, R.O.N.; Fox, B.J. Habitat utilization patterns of sympatric populations of Pseudomys gracilicaudatus and Rattus lutreolus in coastal heathland: A multivariate analysis. Aust. J. Ecol. 1995, 20, 427-441. [CrossRef]

77. Ellwood, E.R.; Bart, H.L., Jr.; Doosey, M.H.; Jue, D.K.; Mann, J.G.; Nelson, G.; Rios, N.; Mast, A.R. Mapping Life-Quality Assessment of Novice vs. Expert Georeferencers. Citiz. Sci. Theory Pract. 2016, 1, 4. [CrossRef]

78. Peterman, K.; Bevc, C.; Kermish-Allen, R. Turning the King Tide: Understanding Dialogue and Principal Drivers in an Online Co-Created Investigation. Citiz. Sci. Theory Pract. 2019, 4, 3. [CrossRef]

79. Phillips, C.; Walshe, D.; O’Regan, K.; Strong, K.; Hennon, C.; Knapp, K.; Murphy, C.; Thorne, P. Assessing Citizen Science Participation Skill for Altruism or University Course Credit: A Case Study Analysis Using Cyclone Center. Citiz. Sci. Theory Pract. 2018, 3, 6. [CrossRef]

80. Spicer, H.; Nadolny, D.; Fraser, E. Going Squirrelly: Evaluating Educational Outcomes of a Curriculum-aligned Citizen Science Investigation of Non-native Squirrels. Citiz. Sci. Theory Pract. 2020, 5, 14. [CrossRef]

81. Tyson, A. NOLS and Nutcrackers: The Motivations, Barriers, and Benefits Experienced by Outdoor Adventure Educators in the Context of a Citizen Science Project. Citiz. Sci. Theory Pract. 2019, 4, 20. [CrossRef]

82. Berenson, M.L.; Levine, D.M.; Krehbiel, T.C. International Edition Basic Business Statistics: Concepts and Applications, 10th ed.; Pearson Education Inc.: London, UK, 2006.

83. Moore, D.S. The Basic Practice of Statistics, 4th ed.; W.H. Freeman and Company: New York, NY USA, 2007; pp. 392-396.

84. Meng, X.F.; Zhang, Z.W.; Li, Z.; Wu, X.J.; Wang, Y.J. The effects of city-suburb-exurb landscape context and distance to the edge on plant diversity of forests in Wuhan, China. Plant. Biosyst. Int. J. Deal. All Asp. Plant. Biol. 2015, 149, 903-913. [CrossRef]

85. Ballantyne, M.; Pickering, C.M.; McDougall, K.L.; Wright, G.T. Sustained impacts of a hiking trail on changing windswept feldmark vegetation in the Australian Alps. Aust. J. Bot. 2014, 62, 263-275. [CrossRef]

86. Environmental Protection Branch. Visual Fuel Load Guide for the Swan Coastal Plain and Darling Scarp, 3rd ed.; Department of Fire and Emergency Services: Perth, Australia, 2015. Available online: https://www.dfes.wa.gov.au/safetyinformation/fire/bushfire/VisualFuelLoadsPublications/ Visual\%20Fuel\%20Load\%20Guide\%20Swan\%20Coastal.pdf (accessed on 30 November 2020).

87. Hines, F.; Tolhurst, K.G.; Wilson, A.A.G.; McCarthy, G.J. Overall Fuel Hazard. Assessment Guide, 4th ed.; Victorian Government Department of Sustainability and Environment: Melbourne, Australia, 2010. Available online: https://www.ffm.vic.gov.au/_data/assets/pdf_file/0005/21110/Report-82-overall-fuelassess-guide-4th-ed.pdf (accessed on 30 November 2020).

88. Volkova, L.; Sullivan, A.L.; Roxburgh, S.H.; Weston, C.J. Visual assessments of fuel loads are poorly related to destructively sampled fuel loads in eucalypt forests. Int. J. Wildland Fire 2016, 25, 1193-1201. [CrossRef]

89. Google Earth. Map Data: Google. Location: $31^{\circ} 58^{\prime} 19^{\prime \prime}$ S $115^{\circ} 46^{\prime} 26^{\prime \prime}$ E. Available online: https://earth.google.com/web/search/31\%c2\%b058\%e2\%80\%9919\%e2\%80\%9dS+115\%c2\%b046\%e2 $\% 80 \% 9926 \%$ 2\%80\%9dE/@-31.9719444,115.7738889,7.82063089a,879.9736776d,35y,0h,45t,0r/data=Cm QaOhI0GcSHI1nR-D_AITEPT2WH8VxAKiAzMcKwNTjigJkxOeKAnVMgMTE1wrA0NuKAmTI24oCd RRgCIAEiJgokCaFyKOKg7BBAEYwREm1foUHAGaCEtEBPAFZAIfIBmwjMOWbAKAI (accessed on 21 November 2020). 
90. Google Earth. Map Data: Google. Location: $32^{\circ} 04^{\prime} 31^{\prime \prime}$ S $115^{\circ} 49^{\prime} 57^{\prime \prime}$ E. Available online: https://earth.google.com/web/search/32\%c2\%b004\%e2\%80\%9931\%e2\%80\%9dS+115\%c2\%b049\%e2 \%80\%9957\%e2\%80\%9dE/@-32.0752778,115.8325,28.89861568a,878.8789933d,35y,0h,45t,0r/data=CmQa OhI0GbOO9LOiCUDAIeF6FK5H9VxAKiAzMsKwMDTigJkzMeKAnVMgMTE1wrA0OeKAmTU34oCd RRgCIAEiJgokCbPX0w1WCUDAEZbmmiGMCkDAGdBhhlLN9VxAIT66Kiqq9FxAKAI (accessed on 21 November 2020).

Publisher's Note: MDPI stays neutral with regard to jurisdictional claims in published maps and institutional affiliations.

(C) 2020 by the authors. Licensee MDPI, Basel, Switzerland. This article is an open access article distributed under the terms and conditions of the Creative Commons Attribution (CC BY) license (http://creativecommons.org/licenses/by/4.0/). 